\title{
Prosopography, Networks, Life Course Sequences, and So On Quantifying with or Beyond Bourdieu?
}

Rossier, Thierry

Document Version

Accepted author manuscript

Published in:

Bulletin of Sociological Methodology / Bulletin de Methodologie Sociologique

DOI:

$10.1177 / 0759106319880148$

Publication date:

2019

License

Unspecified

Citation for published version (APA):

Rossier, T. (2019). Prosopography, Networks, Life Course Sequences, and So On: Quantifying with or Beyond Bourdieu? . Bulletin of Sociological Methodology / Bulletin de Methodologie Sociologique , 144(1), 6-39. https://doi.org/10.1177/0759106319880148

Link to publication in CBS Research Portal

\section{General rights}

Copyright and moral rights for the publications made accessible in the public portal are retained by the authors and/or other copyright owners and it is a condition of accessing publications that users recognise and abide by the legal requirements associated with these rights.

Take down policy

If you believe that this document breaches copyright please contact us (research.lib@cbs.dk) providing details, and we will remove access to the work immediately and investigate your claim. 


\section{Prosopography, Networks, Life Course Sequences, and So On: Quantifying with or Beyond Bourdieu?}

\section{Thierry Rossier}

Journal article (Accepted manuscript*)

\section{Please cite this article as:}

Rossier, T. (2019). Prosopography, Networks, Life Course Sequences, and So On: Quantifying with or Beyond Bourdieu?. Bulletin of Sociological Methodology / Bulletin de Methodologie Sociologique, 144(1), 6-39. https://doi.org/10.1177/0759106319880148

DOI: https://doi.org/10.1177/0759106319880148

Copyright (ㅇ The Author(s) २०19. Reprinted by permission of SAGE Publications.

* This version of the article has been accepted for publication and undergone full peer review but has not been through the copyediting, typesetting, pagination and proofreading process, which may lead to differences between this version and the publisher's final version AKA Version of Record.

Uploaded to CBS Research Portal: August २०२० 


\title{
Prosopography, Networks, Life Course Sequences, and so on. Quantifying with or beyond Bourdieu?
}

\author{
Thierry Rossier ${ }^{1}$
}

\begin{abstract}
This article focuses on the importance of quantifying Bourdieu's "research programme", linked with the concepts of field, habitus, and capital. It presents possible ways of doing statistics within this framework and argues that continuous methodological development should be pursued. To support this argument, the paper highlights the methodology and empirical results of a doctoral dissertation on the Swiss field of economic sciences. It stresses the relevance of using a prosopographical strategy and advocates further development of multiple correspondence analysis, and the use of sequence analysis and social network analysis. The main contributions of these methods concern the investigation of subgroup profiles in fields, the trajectories of accumulation and conversion of capitals and the structure of social capital. When asking whether or not we should think with or beyond Bourdieu when suggesting new methodological developments to his programme, this article argues that we ought to think beyond his strict written work, but still within his theoretical framework, which proves particularly relevant to the study of power relations among individuals.
\end{abstract}

\section{Résumé}

Prosopographie, réseaux, séquences de parcours de vie, etc. Quantifier avec ou par-delà Bourdieu ? Cet article se centre sur l'importance de quantifier le «programme de recherche » de Bourdieu, lié aux concepts de champ, d'habitus et de capital. Il présente de possibles manières de faire des statistiques dans ce cadre conceptuel et soutient qu'un continuel développement méthodologique devrait être entrepris en ce sens. Pour étayer cet argument, ce papier met en lumière la méthodologie et les résultats empiriques d'une thèse de doctorat portant sur le champ des sciences économiques en Suisse. Il insiste sur la pertinence d'une stratégie prosopographique et plaide en faveur de nouveaux développements de l'analyse des correspondances multiples, et de l'usage de l'analyse de séquences et de l'analyse de réseaux. La principale contribution de ces méthodes est d'investiguer le profil de sous-groupes dans les champs, de travailler sur les trajectoires d'accumulation et de conversion de capitaux et sur la structure du capital social. Lorsque l'on se pose la question de savoir si l'on doit penser avec ou dépasser Bourdieu alors que l'on entreprend de nouveaux développements méthodologiques dans le cadre de son programme, cet article soutient que l'on doit penser audelà de ses propres écrits, mais toujours dans son cadre conceptuel, qui s'avère particulièrement pertinent pour étudier les relations de pouvoirs entre individus.

\footnotetext{
${ }^{1}$ Postdoctoral researcher. Department of Organization, Copenhagen Business School, Kilevej 14, DK-2000 Frederiksberg. Mail: Thierry.Rossier@unil.ch.
} 


\section{Keywords}

Bourdieu; prosopography; multiple correspondence analysis; social network analysis; sequence analysis

\section{Mots-clés}

Bourdieu; prosopographie; analyse des correspondances multiples; analyse de réseaux; analyses de séquences

\section{Introduction}

Pierre Bourdieu's early work on Kabylia was rather ethnographical and qualitative (Bourdieu, 1962). However, with his growing ambition to turn his theorization of social relations into a "research programme" (Lebaron, 2015: 54), Bourdieu increasingly relied on statistics and quantification $^{2}$ as a (non-exclusive) methodology in his studies. One of his most famous statistical ambitions can be found in Chapter 2 of Distinction (1984), where he proposes (with a theoretical diagram) to quantify the volume and the share of both cultural and economic capital within the entire French social space. He is also well-known for being one of the pioneers in the use of multiple correspondence analysis (MCA) in sociology, a method which was consistent with his relational and spatial way of thinking. However, some scholars working in a Bourdieusian framework, despite calls for systematization and further developments of quantitative analyses ${ }^{3}$, tend to use only the basic features of MCA, and generally distrust other relational methods such as social network analysis. Nonetheless, these methods, if used properly, constitute a real input to further explore and understand old and new features concerning fields, habitus and capitals.

The objective of this article is twofold. First, I argue that in the framework of Bourdieu's research programme, quantitative analyses are more than useful to study the structure of fields and forms of capital, even if Bourdieu wrote several books devoid of any statistics. Indeed, while qualitative methods serve the purpose of conducting ex ante explanatory research and exemplifying particular configurations of a social structure, quantitative analyses permit researchers to describe structural tendencies regarding fields, capitals and habitus ${ }^{4}$. I present possible ways of doing statistics when using Bourdieu's framework in sociological research. Second, since Bourdieu's programme was developed in a particular national context (mainly France) and a particular period of time (between the 1950s until Bourdieu's death in 2002), it necessarily ignores some recent developments of sociology as well as some topics and methods developed elsewhere. Instead of opposing an alleged Bourdieusian "orthodoxy" (Cousin et alii., 2018) of "close readers" of the "master's" work, I argue that Bourdieu's

\footnotetext{
${ }^{2}$ Early uses of statistics can be found in: Bourdieu et alii., 1963; Bourdieu and Passeron, 1979[1964]; Darras, 1966; Bourdieu and Darbel, 1979[1966].

3 To my knowledge, at least six books focus on the interrelations between Bourdieu's programme and quantitative methods, and try to go beyond Bourdieu's use of quantitative analyses: Robson and Sanders, 2009; Grenfell and Lebaron, 2014; Lebaron and Le Roux, 2015; Coulangeon and Duval, 2013, 2015; Blasius et al., 2019.

${ }^{4}$ Quantitative and qualitative methods are to be thought of as complementary. Exploratory ethnography and participant observation, interviews, or historical source reading lead to understanding the specific capital of a field, which in turn leads to the systematic collection of indicators (through questionnaire survey or prosopography) to describe tendencies of capital detention, which finally lead to selection of individuals representing particular fractions of capital detention for further interviews or sources reading.
} 
programme should not be strictly limited to only Bourdieu's work, but be part of a larger and more dynamic community, with continuous development. When asking the question of whether or not we should think with or beyond (or against) Bourdieu when suggesting new methodological developments to his programme, I argue that we should think beyond his written work (Atkinson, 2016), but still within his theoretical framework, which proves to be among the most relevant in the study of power relations between individuals.

To do so, I share my own research experience, acquired during my doctorate at the University of Lausanne (August 2013-June 2017) and which continued until the writing of this paper. It focused on the historical rise and transformations of economics and business studies in Swiss universities. To study the structure of the Swiss scientific field of economic sciences, I relied mainly on a biographical database of all the professors in the twelve Swiss universities at five benchmark-dates (1910, 1937, 1957, 1980, and 2000), but supplementary data had been collected (and continues to be completed even now), for the professors before and between the initial five dates, and until the recent period $(2017)^{5}$.

The paper is organised as follows. In a first theoretical part, I present Bourdieu's research programme, in particular regarding the concepts of fields, capital and habitus. In the core of this article, I insist on four particular developments regarding Bourdieu and statistics: at the level of data collection strategy, I focus on prosopography; at the level of data analysis, I focus on three methods (multiple correspondence analysis, sequence analysis, and social network analysis). I explain the relevance of each method regarding Bourdieu's theoretical framework and give examples of how I used them during my doctoral work. Their main inputs are to identify and investigate subgroup profiles in fields, to analyse trajectories of accumulation and conversion of capitals, and the structure of social capital. After that, I summarize the research questions and outline the main findings of my doctoral dissertation, and show how the combination of these methods helped me in the process of obtaining these results. In conclusion, I come back to my main arguments and propose further use of new methods.

\section{Bourdieu's Research Programme: Fields, Capitals, and Habitus}

According to Swartz (1997: 285), Bourdieu's “political economy of symbolic power is perhaps the most ambitious and consequential project for the symbolic realm since that of Talcott Parsons". Bourdieu developed a "research programme" with the ambition of being applicable to all types of societies, in order to unveil reproduction of power relations among individuals and groups. It focuses on how stratified social systems of domination and competitive hierarchies persist and reproduce without explicit resistance and without the conscious recognition of individuals. Power stands at the heart of social life and its exercise requires legitimation through symbolic forms, which constitute and maintain power structures. The struggle for social distinction is a fundamental dimension of social life, where forms of capitals, with specific laws of accumulation, exchange and exercise, play a critical role. Bourdieu addresses the relationship between individual agency and social structure by proposing a theory of practice, which connects action to structures, and which undergirds his concept of habitus. Practices occur in structured arenas of conflict called fields, which connect the action of habitus to the stratifying structures of power. Sociology's aim is to perform "socioanalysis", where the task of the researcher is to unveil the "social unconscious" of

\footnotetext{
${ }^{5}$ The full text of my PhD dissertation (Rossier, 2017), in French, can be found here: https://serval.unil.ch/notice/serval:BIB 291ECA5B41BC.
} 
society, i.e. the hidden dimension of power relations, in order to undermine their legitimacy. And because social sciences are themselves not exempt from processes of social differentiation, they have to be undertaken under the guide of "reflexivity", understood as a rigorous self-critical practice (Swartz, 1997). While developing his theory, Bourdieu conceived several conceptual tools, which are inter-related and function as a system (Savage et alii., 2005). In particular three ${ }^{6}$ concepts are critical to understand Bourdieu's research programme: fields; capitals; and habitus ${ }^{7}$.

A field is a relatively autonomous social space, which is defined by its object of dispute and the specific stakes related to this object (Bourdieu and Wacquant, 1992; Savage and Silva, 2013). Agents struggle for the detention of the "specific" capital of the field and/or its redefinition. This capital is unequally distributed, ergo there are dominant and dominated individuals, occupying positions according to the volume and composition of the resources they detain. This unequal distribution determines the structure of the field (Bourdieu, 1996a; Lahire, 1999). Fields can refer to a variety of social entities, such as professions (law, medicine...), academic disciplines, arts, politics, or the private and public economic sectors. The dominant individuals of all the other fields are themselves involved in the "field of power", a field where the stake is to detain power over all the other sources of power (i.e. possess a capital which confers power on all the other capitals; Bourdieu, 1996b).

Capitals are defined as forms of assets or resources, involved in systemic processes allowing their garnering by those who possess them. Capitals have the potential to accumulate, store and retain advantages. This accumulatory potential sometimes permits to unlock advantages in other fields, by a process of conversion from one capital to another (Savage et alii., 2005). Capitals can take various forms. Economic capital corresponds to material advantages within mercantile relationships. Cultural capital is related to (immaterial) cultural and educational resources. Social capital refers to the aggregate of the actual or potential resources, which are linked to the possession of a durable network of relationships of mutual acquaintance and recognition. Symbolic capital refers to each form of capital that is unrecognized as a capital and recognized as a legitimate competence (Bourdieu, 1986). Finally, a specific capital relates to every field's particular capital.

Habitus is a system of long-lasting and transposable embodied dispositions, which, as a structure, have been structured by the social environment of the individuals, but also work as structuring devices, in the sense that they generate and organize practices and representations (Bourdieu, 1990, 2000). Habitus organizes the ways that individuals act, think, feel, and perceive. In fields, habitus is a mediating concept between the space of positions of the individuals, defined by the overall structure of capitals they detain, and the space of positiontakings, which corresponds for example to the production of a particular piece of art in the artistic field, or a particular scientific work in the scientific field, as well as to the critical

\footnotetext{
${ }^{6}$ Other concepts of his are important: for example, "symbolic power", "symbolic violence", and doxa (Bourdieu and Passeron, 1990). Nonetheless, since (symbolic) domination and power are inherent in every field, incorporated through habitus, and exercised as a mean of domination through symbolic capital, I will not develop further here this set of concepts.

${ }^{7}$ Scholars who want to develop further their knowledge of these concepts should read references cited in this section, which constitute some of their more important theorization, whether in Bourdieu's or his reception's (Savage et al., Lahire, Swartz, Grenfell, etc.) writings.
} 
judgement on the production of other individuals actively involved in the field. Habitus implies a structural homology between these two spaces (Bourdieu, 1996a).

In a more analytical dimension, Bourdieu sums up his methodological approach in terms of three levels. First, one must study the relation to each field vis-à-vis the field of power and see whether individuals from this field are situated in a dominant or a dominated position within this space. Second, the researcher must map the objective structures of relations between the positions occupied by agents involved in the field, through configurations of capital detention. Third, one must analyse the habitus of agents, the different systems of dispositions they have acquired by internalizing a determinate type of social and economic conditions, which, through a particular trajectory within the field, have found a more or less favourable opportunity to be actualised (Bourdieu and Wacquant, 1992; Grenfell, 2014). This threelayered methodology of field analysis implies to consider that the concepts of field, capital and habitus are inter-related, that they function as a system and must not be analysed separately.

In the following sections, I focus on the methodological strategy and the use of quantitative methods in my $\mathrm{PhD}$ dissertation that are linked to the development of Bourdieu's framework and conceptual tools. In the first section dedicated to data collection strategy, I define and exemplify prosopography. The second section focuses on methods of data analysis and I concentrate on three particular techniques: multiple correspondence analysis, sequence analysis, and social network analysis. Each time, I give examples of applications of these methods from my own work.

\section{Bourdieu and Prosopography: A Data Collection Strategy}

Prosopography consists in the investigation of the common background characteristics of a group of individuals by means of a collective study of their lives (Stone, 1971). Prosopography originated from the discipline of history (Charle et alii., 1980). Its core idea is to delimit a group based on certain (often objective) characteristics, and, on the basis of an available corpus of sources, to collect systematic data on a given set of indicators concerning their social properties, in order to understand certain social mechanisms present in particular groups (Lemercier and Picard, 2011).

A prosopographical approach in Bourdieusian studies is not new and probably can be traced back in the early 1970s. It is linked to the ambition of gathering systematic data on individuals belonging to the same field. This collection of data should correspond to their resources associated with social origins, educational backgrounds, trajectories and position in the global social space and in the field, measured through detention of specific capital, and their position-taking in matters crucial to the field. The object of study is not the individuals per se, but rather the field's history and structure, which also leads to understanding individual dispositions (Broady, 2002). Bourdieusian prosopography equally allows quantitative analysis of common trajectories and qualitative focus on particular individual cases, as long as both are understood in the framework of the social structure of the field. Such a strategy implies a circumscription of the population and a thorough knowledge of what is at stake in the field before collecting the data, as well as a constant development of the collection of new 
indicators. Data collection works as a discovery process, where new meanings of indicators are found, which provides a very inductive knowledge of the field.

Prosopography was central to my doctoral work, and allowed qualitative and quantitative insights into the Swiss field of economic sciences. Data collection took place out of a collective effort, as part of a research project on academic elites ${ }^{8}$ related to the "Swiss elite database" 9 platform, created more than ten years ago, and currently containing biographical entries on more than 35,000 members of Swiss elites. Elites are defined, according to a positional definition (Mills, 1956), as the individuals who sit at the helm of the most important (economic, political, academic...) institutions of Swiss society (for some references using these data, see for example: Bühlmann et al. 2012a, 2012b, 2013, 2017; Rossier et al., 2017; Eichenberger \& Ginalski, 2017).

The field was delimited on the basis of the position of university professor in economic sciences. To identify this population, I relied on a source centralising all the academic personnel in Switzerland: the Swiss university directories (Jahrbuch der schweizerischen Hochschulen), which was published between 1907 and 2008. I completed the collection of professor names with the help of university annual reports. To collect systematic biographical data, I relied on several sources: the Swiss Historical Dictionnary, the Who's Who in Switzerland, several university anniversary monographs, university annual reports, necrologies in newspaper archives, online curricula, information within $\mathrm{PhD}$ dissertations, university archives, and internal digital databases. The Swiss elite database is a relational database, constituted of multiple linked tables. Three tables were particularly relevant for this collection: a table centred on individual properties (such as social origins and diplomas); a table centred on institutions (for example, University of Zurich, University of Geneva, etc.); both tables linked by several professional functions collected in a mandate table with a date of beginning and a date of end (e.g. "full professor 1988-1999") ${ }^{10}$.

I collected information on such properties as education, careers, and academic work of these professors. Two properties were particularly challenging to find systematically: occupation and religious confession of the parents. Those inherited properties are often kept silent in the public biographies, since they are part of the "private" life. I had to abandon the idea of treating them quantitatively at some point. Besides these, I coded the sex of the professors. Also, effective resources composing the specific capital of the field were collected. Indicators of institutional academic power resources were: university vice-chancellor; department dean; board member of disciplinary societies; board member of diverse academic societies. Indicators of external resources were: board member or executive director of corporation; board member or executive director of the 110 largest Swiss firms; board member of the main economic interest associations; member of the federal parliament or government, or a cantonal government; senior civil servant (head of a federal office, central bank governor, etc.); member of an expert committee for the federal administration; place in the Neue Zürcher Zeitung (one the most important Swiss newspapers) ranking of economists (held since 2014). Indicators of social capital were: number of members of the Swiss political, administrative, economic, and academic elites of which the professor has supervised the $\mathrm{PhD}$

\footnotetext{
${ }^{8}$ This project (no 100017_143202) was funded by the Swiss National Science Foundation, and was supervised by Felix Bühlmann, André Mach, and Thomas David.

${ }^{9}$ https://www2.unil.ch/elitessuisses/.

${ }^{10}$ Figures 1-3 give an example of an individual file in these tables.
} 
thesis; number of elite members having the same $\mathrm{PhD}$ supervisor; number of co-applicants in a research project funded by the Swiss National Science Foundation (SNSF). As indicators of international resources, I considered the following: citizenship(s) at birth; country of the $\mathrm{PhD}$; different countries of stays outside Switzerland; $\mathrm{PhD}$ in English in a non-English speaking country. For scientific resources, I collected: amount of funding by the SNSF; discipline of the co-applicants of research projects, to have a scale of interdisciplinarity; number of citations in the Web of Science; number of citations in Google Scholar; place in the ranking of authors in the IDEAS/Research Papers in Economics (RePEc) database. Finally, I coded a set of position-takings: use of mathematics and statistical techniques in the $\mathrm{PhD}$ dissertation; domain of specialty.

Table 1 summarizes the number of economics and business professors for the dates considered, as well as their gender and citizenship (at birth) distribution ${ }^{11}$. Three particular trends emerge from this table: 1) There is an increase of proportion of business studies professors during the whole 1910-2000 period; 2) the field is utterly masculine, with no women professors before the 1980s and only a few in the recent period; 3 ) the share of nonSwiss economics professors forms a U-shaped curve, with a large proportion of foreigners at the beginning and the end of the period, meanwhile this internationality is more modest until the 1980s in business studies, but with a large increase since then.

Table 1: Number of economics and business professors and \% of women and Non-Swiss professors (at birth)

\begin{tabular}{|lcccccc|}
\hline \multicolumn{1}{|c}{$\mathbf{1 9 1 0}$} & $\mathbf{1 9 3 7}$ & $\mathbf{1 9 5 7}$ & $\mathbf{1 9 8 0}$ & $\mathbf{2 0 0 0}$ & $\mathbf{2 0 1 7}$ \\
\hline $\mathbf{N}$ & & & & & & \\
Economics & $20(80 \%)$ & $29(59 \%)$ & $38(58 \%)$ & $86(53 \%)$ & $118(45 \%)$ & 232 \\
Business Studies & $5(20 \%)$ & $20(41 \%)$ & $27(42 \%)$ & $75(47 \%)$ & $143(55 \%)$ & - \\
All & $25(100 \%)$ & $49(100 \%)$ & $65(100 \%)$ & $161(100 \%)$ & $261(100 \%)$ & - \\
\hline \% Women & & & & & & \\
Economics & $0 \%$ & $0 \%$ & $0 \%$ & $1 \%$ & $3 \%$ & $10 \%$ \\
Business Studies & $0 \%$ & $0 \%$ & $0 \%$ & $0 \%$ & $8 \%$ & - \\
All & $0 \%$ & $0 \%$ & $0 \%$ & $1 \%$ & $6 \%$ & - \\
\hline \% Non-Swiss & & & & & & \\
Economics & $85 \%$ & $59 \%$ & $29 \%$ & $35 \%$ & $51 \%$ & $68 \%$ \\
Business Studies & $20 \%$ & $15 \%$ & $15 \%$ & $21 \%$ & $51 \%$ & - \\
All & $72 \%$ & $41 \%$ & $23 \%$ & $29 \%$ & $51 \%$ & - \\
\hline
\end{tabular}

Prosopography, as a data collection strategy consisting in the investigation of a set of common properties of a group of individuals, is compatible with a Bourdieusian framework, since it allows working on a delimited field, on the distribution of capitals, and on the homology between positions and position-taking, focusing on particular individual habitus. When Bourdieu himself used prosopography in his works (e.g. Bourdieu, 1988), it is not always clear if he and his team had made their data collection in an equally rigorous manner as historians usually do. Nonetheless, a large group of Bourdieusian scholars have since then used prosopography in a thoroughly rigorous way and it has become one of the "classical" collection strategies to study fields (see for example: Denord et al., 2018; Ellersgaard et al.

\footnotetext{
${ }^{11}$ As biographical information on professors in 2017 was collected after having finished my $\mathrm{PhD}$ dissertation as part of a more precise focus on economics, information on business professors are therefore missing at this point.
} 
2012, 2019; Timans and Heilbron, 2018; Karády and Nagy, 2019; Hjellbrekke and Korsnes, 2018; Dalberg, 2019; Lundig, 2017; as well as all the works using the Swiss elite data cited earlier). However, proposography in itself only allows basic statistical features, such as counting the absolute or relative shares of certain properties. In order to go a step further in the comprehension of a field, we need statistical techniques, which account for the description of its structure, among others in a multivariate perspective.

Figures 1-3: Swiss elite database. Example of a biographical file: the monetarist economist Karl Brunner (Professor in Bern between 1974 and 1986)

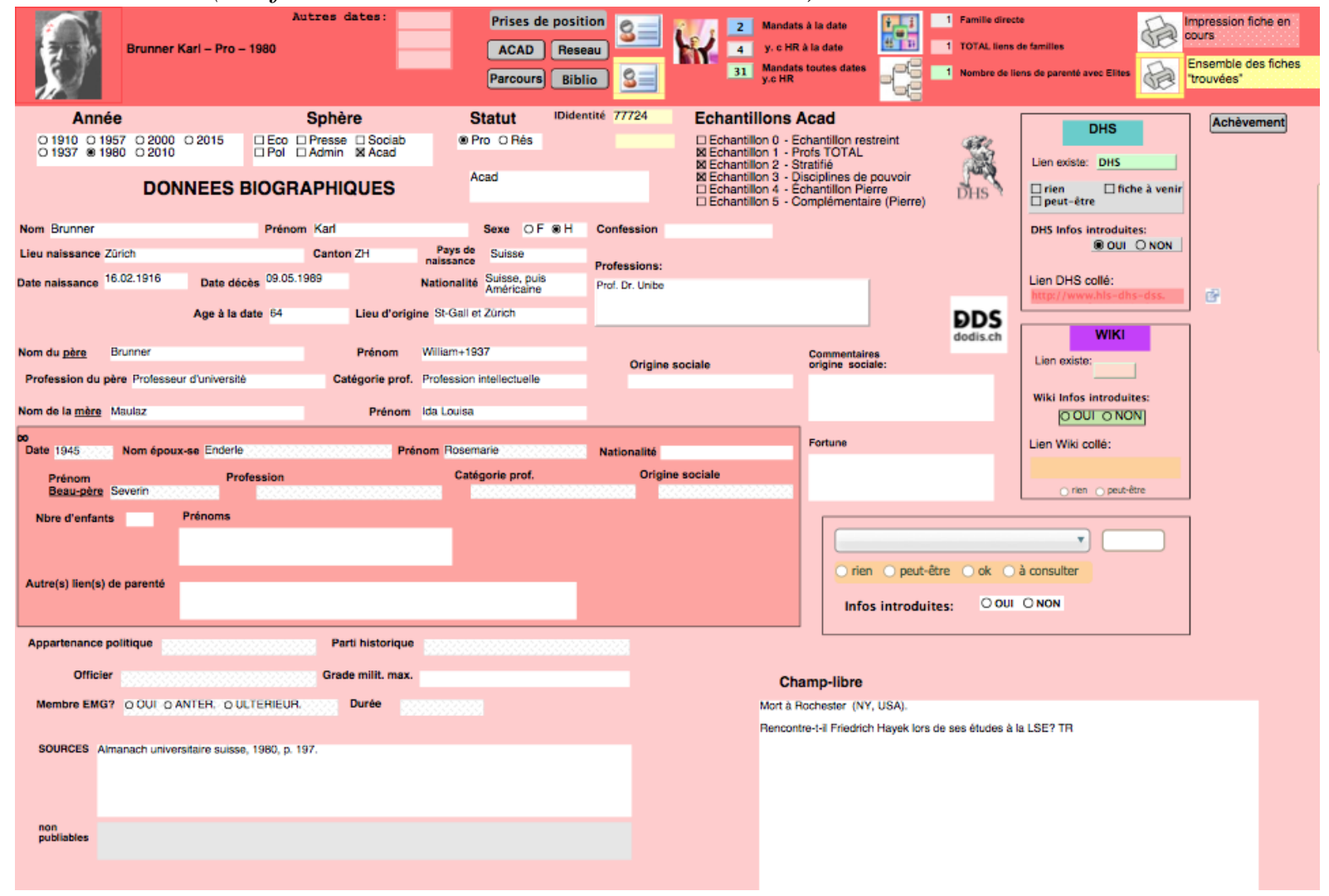



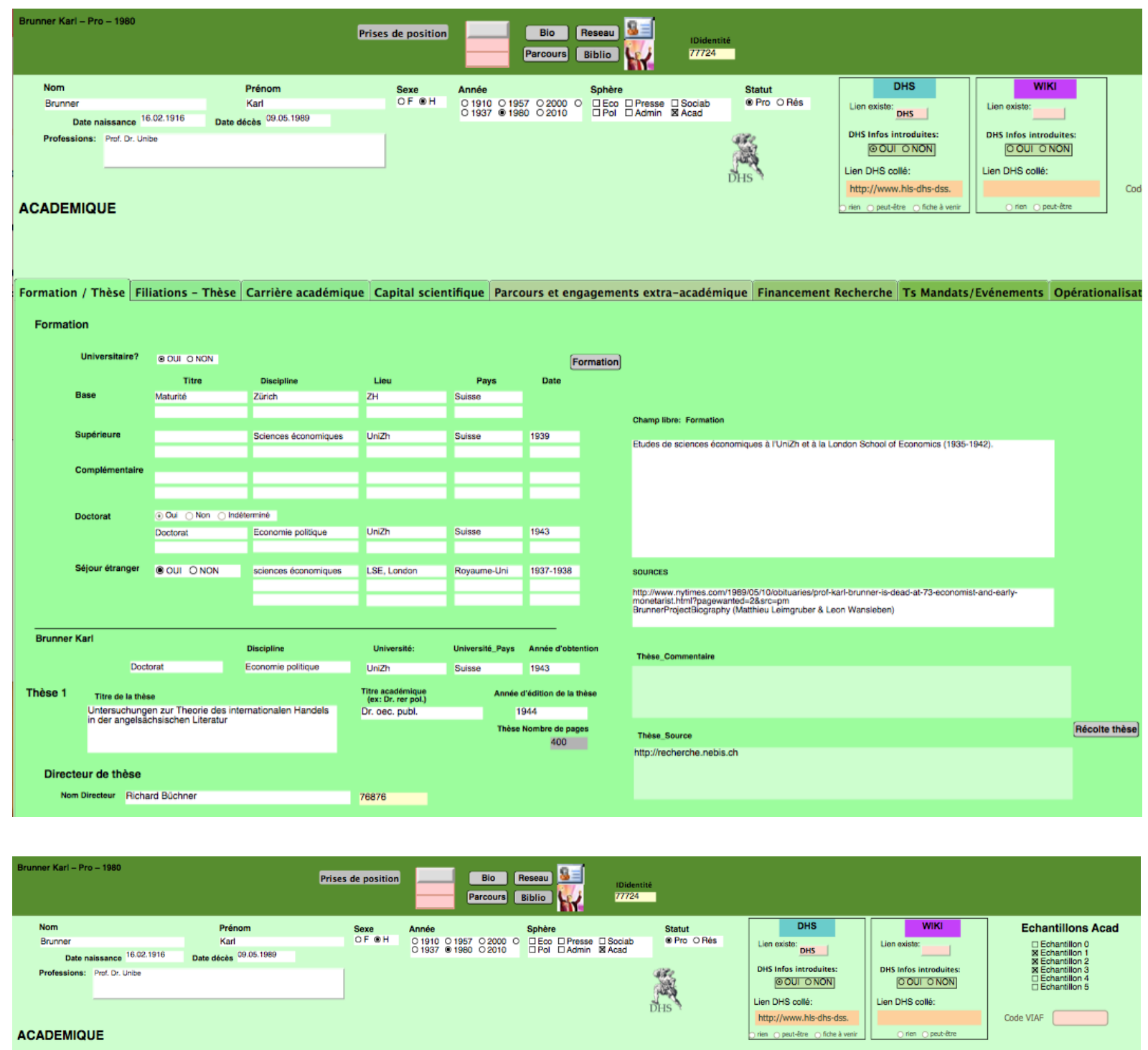

\begin{tabular}{|c|c|c|c|c|c|c|c|c|c|c|c|}
\hline Formation & / Thèse Filit & ations - Thèse & Carrière aca & démique Capita & al scientifique Parcours & et engagements extra & -académique & Financement Recherche & Ts Mandats/Evénements & ts Opérationa & nalisation Dr Droit \\
\hline Maviven & Annexupprine & Sphere & Typo & Fonetion & Entité & Organe & pars & 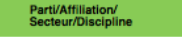 & Echelle / Chaire & DUREE_Fonction & Sourcest \\
\hline Nandat & HR & Administrativ & BNS & Collaborateur de & gNS & & Suisse & 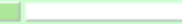 & Fed & 1943-1944 & 10 \\
\hline Nandat & HR & Administrativ & Déparnement & Employe & OFE & Division du commerce & Suisse & DFE & Fed & 1944-1945 & Fratanni 2007, p. 2. \\
\hline Mandat & HR & Académique & Recherche & Chercheour & UnisG & & Suisse & 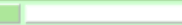 & & 1946-1948 & Who's who in Economics, \\
\hline Nandat & HR & Académique & Enseignement: & Charge de oours & UnisG & & Suisse & J. & & 1946-1949 & Who's who in Economics. \\
\hline Nandat & HR & Eonnomique & Association & Conseiller & Chambre suisse de & & Suisse & HORL & 1 & 1948-1949 & Fratianni, 2007, p. 2. \\
\hline Nandat & HR & Administrativ & Administration & Consultant & ONU & Commission Economique & Suisse & 1. & Inter & 1948-1949 & Fratanni, 2007, p. 2. \\
\hline Nandat & HR & Académique & Enselgnement: & Boursier & Harvard University, University & & USA & 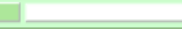 & & | 1949-1951 & DHS \\
\hline Nandat & HR & Académique & Enselgnement & Professeur & University of Callfomia, Los & & USA & Economie politque & & 1951-1957 & Who's who in Economics. \\
\hline Nandat & $\begin{array}{l}\text { Principale } \\
\text { for }\end{array}$ & Académique & Enseignement: & Professeur associé & University of Califomia, Los & & USA & Economie politique & & $1957-1962$ & Who's who in Economics, $\mid O$ \\
\hline Nandat & Principale & Académique & Enseignements & Professeur & University of Califomia, Los & & USA & Economie politque & & 1962-1966 & Who's who in Economics, \\
\hline Nandat & HR & Académique & Enseignement & Profosseur invité & University of Wisconsin- & & USA & 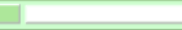 & 1 & 1965-1965 & Who's who in Economics. \\
\hline Nandat & $\mathrm{HR}$ & Academique & Enseignement: & Profoesseur invité & Mchigan State University & & USA & 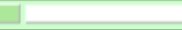 & & 1965-1966 & Who's who in Economics. \\
\hline Nandat & HR & Academique & Enselgnement & Professeur invité & Northwestern University & & USA & . & & 1966-1966 & Who's who in Economics. \\
\hline Evenemement & HR & Académique & PrixxDisisinction & Docteur hononis & Universite Catholique de & & Belgque & ]. & 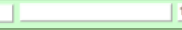 & 1966 & 10 \\
\hline Nandat & $\begin{array}{l}\text { Principale } \\
\text { Pall }\end{array}$ & Academique & Enseignements & Protesseur & Ohio State University & & USA & Economie politque & Chaire Everett Reese & 1966-1971 & DHS \\
\hline Nandat & HR & Académique & Enseignements & Profosseur invité & Universitat: Konstanz & & Allemagne & ב & & 1968-1968 & BrunnerProjectiliography $\mid \mathcal{O}$ \\
\hline Nandat & HR & Académique & Recherche & Fondateur et & Journal of Money, Credit and & & USA & 1 & ] & 1969-1974 & DHS, Who's who in \\
\hline Nandat & HR & Academique & Administration & Fondateur & Séminanares annuels de & & Allemagne & 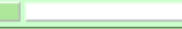 & 1 & | 1970-(1970) & DHS \\
\hline Nandat & HR & Académique & Administration & Directeur & University of Rochester & William E. Simon Graduate & USA & ב. & & $\geq 1971$ & hitpo://www. nytimes. \\
\hline Mandat & Principale & Academique & Enseignements & Protesseur & University of Rochester & William E. Simon Graduate & USA & Economie politque & Chaire Fred H. Gowen & 1971-1889 & nttp: $/ /$ www.nyimes. \\
\hline
\end{tabular}




\section{Bourdieu and Quantitative Methods}

In this section, I develop three quantitative methods: multiple correspondence analysis (MCA); sequence analysis (SA); social network analysis (SNA). Each time I trace parallels with Bourdieu's research programme and insist on new developments of quantitative analysis within Bourdieu's framework using my dissertation as a material. These three methods allow classifying/categorizing and identifying subgroups, as well as working on typologies and subgroup profiles, but I mostly focus on MCA for this matter. SA permits us to work on the temporality of individual lives, by looking at trajectories of capital accumulation and conversion. Finally, with SNA, one can study the configuration of a particular capital, i.e. social capital, especially its composition, its size, and the more or less favourable position of individuals in a whole network based on several measures of centrality. I develop these different contributions more in detail in the following sections. Each of these methods has been used and developed in social sciences in association with a particular body of theoretical literature. MCA was developed amongst others with Bourdieusian literature, but new features of the method can draw bridges with other sociological theories or other disciplines. Sequence analysis was used first in sociology by Andrew Abbott and is currently used by life course sociologists. Social network analysis is the method of sociologists working on inter-individual ties and connections. By using these methods, I am able to establish a dialogue between Bourdieu's research programme and other theories.

\subsection{New Developments of Multiple Correspondence Analysis: Study of Subgroups}

Multiple correspondence analysis (MCA) has been the most widely used method of quantifying with Bourdieu. Bourdieu himself used this method on several occasions (e.g. Bourdieu, 1988, 1996b, 2005).

MCA consists of a geometric representation of the structures of a multiple crosstable between a set of active variables, in the sense that they contribute to construct the space. The complexity of the association between these variables is reduced through different dimensions of oppositions among levels of variables. The first dimension, or axis, represents the most dominant opposition, the second axis the second most dominant, etc. Each axis constitutes a dimension in a multi-dimensional space, and each level of a variable and each individual is located as a point in this space. The closer individuals are in the multidimensional space, the more likely they are to share properties in common. Conversely, the closer levels of variables are in the space, the larger is the group of individuals who tends to share them. A set of illustrative or supplementary variables, which do not contribute to the construction of the space, can be projected into this space. The contribution from a given level of variable or a variable to an axis indicates its importance to the construction of the axis. Levels of variables and variables with a contribution above the average contribution are emphasized in the interpretation of the axes. We normally interpret a certain number of axes given indicators of their explained variance, of inertia ${ }^{12}$ (Hjellbrekke, 2018; Le Roux and Rouanet, 2010).

\footnotetext{
12 Among them the eigenvalue or the percentage rate of variance; we normally follow the indicator of the modified inertia rates, which constitute a recalculation of the eigenvalues. We generally retain all the axes, which represent at least $80 \%$ of the cumulated modified rates (i.e. the sum of the modified rates of the first axes). For more detail, see Hjellbrekke (2018: 36-37).
} 
Bourdieu was among the first sociologists to use this method (even though he did not do the analyses himself). He found it particularly attractive, since it allows to spatialize individuals on the basis of their social properties and resources, projected as active variables. Individuals are situated in a particular position within the field. Thereafter, a set of position-takings can be projected as illustrative variables, and the homology between the space of positions and the space of position-takings can be uncovered. On this basis the existence of particular individual habitus can be deduced and the specific capital of the field can be visualised through the different resources of individuals. Bourdieusian scholars continued to use this method until recently ${ }^{13}$. Nonetheless, even if MCA has been widely used for a long time, (old and new) developments of the method have not necessarily always been exploited. I recommend it for the study of subgroups within fields, which has not been explored enough until now.

Cousin et alii. (2018) recently argued that too little emphasis has been placed by Bourdieu and Bourdieusian scholars on questions relative to gender and race, and that it is necessary to either amend or move beyond the "orthodox Bourdieusian framework" (Cousin et alii., 2018: 229), by considering diversity, and gendered and racialized relations, among groups. I argue that developments of MCA could help to focus on field diversity by studying subgroups, and that it is not necessary to go beyond a Bourdieusian framework to do so. It is possible to work on two types of subgroups thanks to MCA: subgroups identified empirically, and subgroups identified through a pre-established level of variable, normally projected as illustrative. For the first solution, I recommend using a clustering process to identify groups of individuals. Ascending hierarchical clustering is usually performed. It consists in taking the coordinates of individuals on a given group of axes and using a cluster algorithm (such as the Ward method) to identify groups, where the individuals, based on their position on all the given axes, are the most similar (i.e. close) to each other. At the same time, the groups must be dissimilar from one another. Once the groups identified, and a number of groups have been chosen, we qualify them according to their association to several levels of (active or illustrative) variables (Denord et alii., 2011; Hjellbrekke, 2018).

For the second solution (pre-established modalities), I recommend using class specific MCA (thereafter CSA), which allows studying the specific traits and detention of capitals of a group of individuals, while conserving the distances between these individuals defined in the initial space. To do so, individuals are split into several categories based on a given illustrative variable. Then, CSA is performed on a given subgroup, which allows finding new axes of opposition among this particular set of individuals. Then the principal axes of this subgroup are compared to the axes of the MCA for the whole group by looking for associations between the old and the new axes. Thereafter, the contributions from the active variables to the new axes are compared to the old ones (Hjellbrekke and Korsnes, 2016; Denord et alii., 2018; Bonnet et al., 2015; Roose, 2015; Hjellbrekke, 2018). CSA is particularly useful for working on subgroups, which, depending on data availability, can be coded according to gender, sexuality, race/ethnicity, religion, social class, age, etc.

I give here an example of MCA and CSA, using the group of the professors of economics in Swiss universities in 2017. It allows me to uncover the structure of this disciplinary field and the configurations of its specific capital. I do an MCA with 13 active variables ${ }^{14}$ and 34 active

\footnotetext{
${ }^{13}$ A list of "best practices" can be found in Lebaron (2015: 58).

${ }^{14}$ They are the following: number of citations in Google Scholar; rank in the RePEc ranking; country of the $\mathrm{PhD}$; stay in the US apart from the PhD; dissertation in English in non-English speaking country; "local" career (professor in the same Swiss university where he/she obtained his/her $\mathrm{PhD}$ ); executive board member of a
} 
levels of variables ${ }^{15}$. I retain the first three axes for interpretation ${ }^{16}$. These three axes are represented horizontally in Figures 4-6 (negative coordinates on the left, positive on the right $)^{17}$, by displaying only the levels of variables which contribute to each axis above the average contribution.

Axis 1 displays mostly an opposition linked to internationality related to the US and the UK $v s$. (Swiss) localism, as well as an opposition between scientific vs. "worldly" (i.e. external) resources. Having obtained a doctorate in an Anglo-Saxon country and being ranked high in the RePEc ranking oppose to having obtained a doctorate in Switzerland and to a high volume of institutional capital, such as occupying executive positions in Swiss institutions (corporations, expert committee, faculty dean...) or being recognized in the Swiss medias. Axis 2 is structured according to the volume of scientific and academic power resources and different international resources. Resources linked to a high number of citations in Google Scholar as well as positions of faculty dean and member of the executive committee of academic organisations oppose to a lower number of citations and a lower rank in the $10 \%$ $R e P E c$ ranking. Likewise, a $\mathrm{PhD}$ obtained in the US opposes to a $\mathrm{PhD}$ obtained in Germany (combined with international resources linked to the US for individuals who have not obtained their $\mathrm{PhD}$ there). Finally, Axis 3 mainly displays an opposition between absence vs. a high volume of scientific resources: no Google scholar profile and no position in the $10 \%$ $R e P E c$ ranking opposes to high volumes of resources according to these same indicators.

corporation; non-executive board member of a corporation; position in the Neue Zürcher Zeitung ranking of economists; expert committee member for the Swiss federal administration; member of the board of the Swiss Society of Economics and Statistics; department dean; science policy "mandarin" (board member of important scientific societies).

${ }^{15}$ Analyses are done with the $R$ package soc.ca (Larsen et alii., 2016).

${ }^{16}$ Axis 1 accounts for $56.5 \%$ of the modified rates, Axis 2 for $21.4 \%$, and Axis 3 for $12.1 \%(90.0 \%$ of the cumulated modified rates in total).

17 We normally should not trust visual representation of variables in MCA and rather read tables of the contribution of variables and levels of variables to each axis, in order to interpret our results. Nonetheless, in order to save space, these tables are not presented, but they are available upon request to the author. 
Figure 4: Space of the professors of economics in 2017 ( $n=232$ ), Cloud of modalities (axis 1; axis 2 on ordinate)

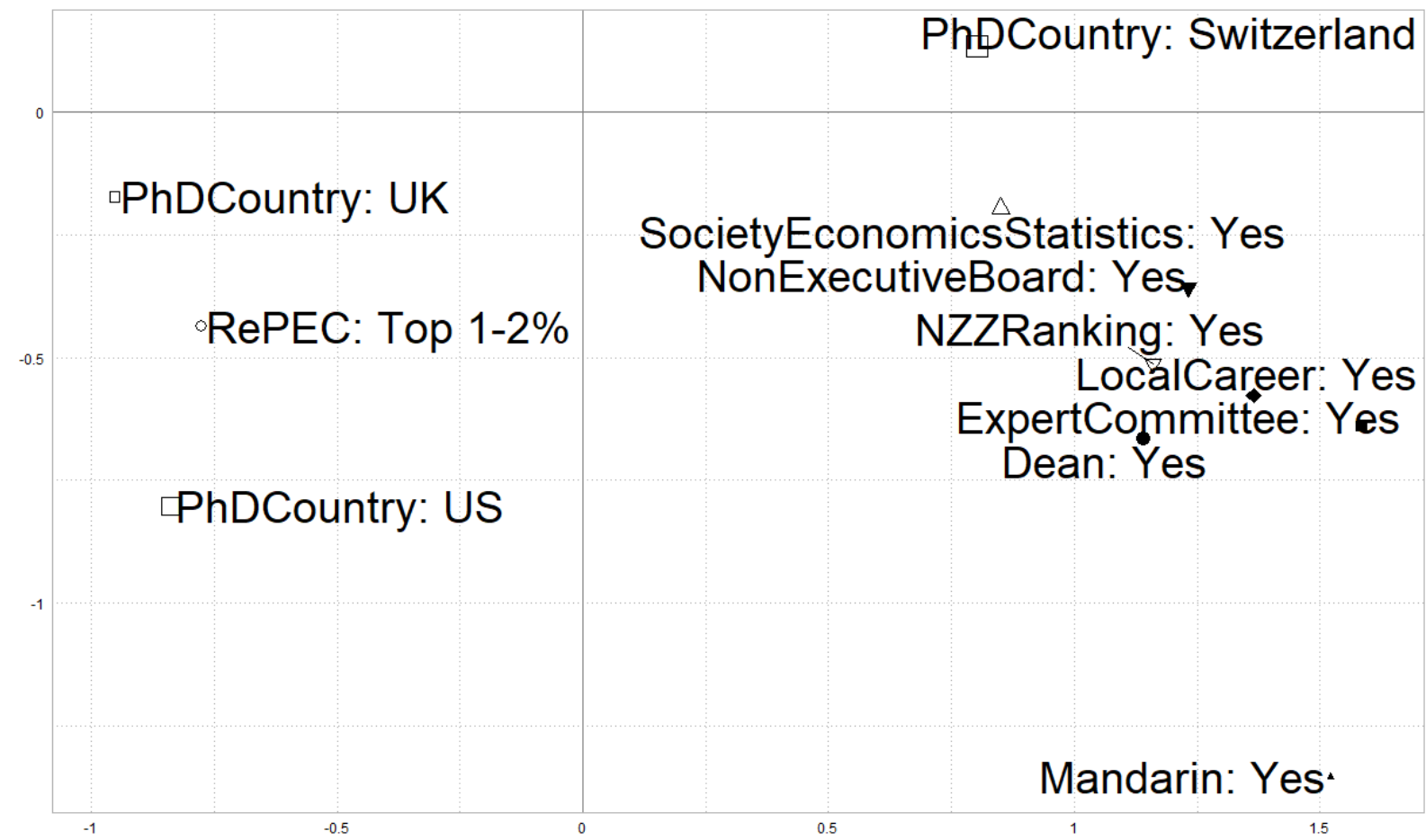

Notes: Left of the space: International (US and UK) and scientific capitals. Right of the space: Local (Swiss) and "worldly" capitals. 
Figure 5: Space of the professors of economics in $2017(n=232)$, Cloud of modalities (axis 2; axis 1 on ordinate)

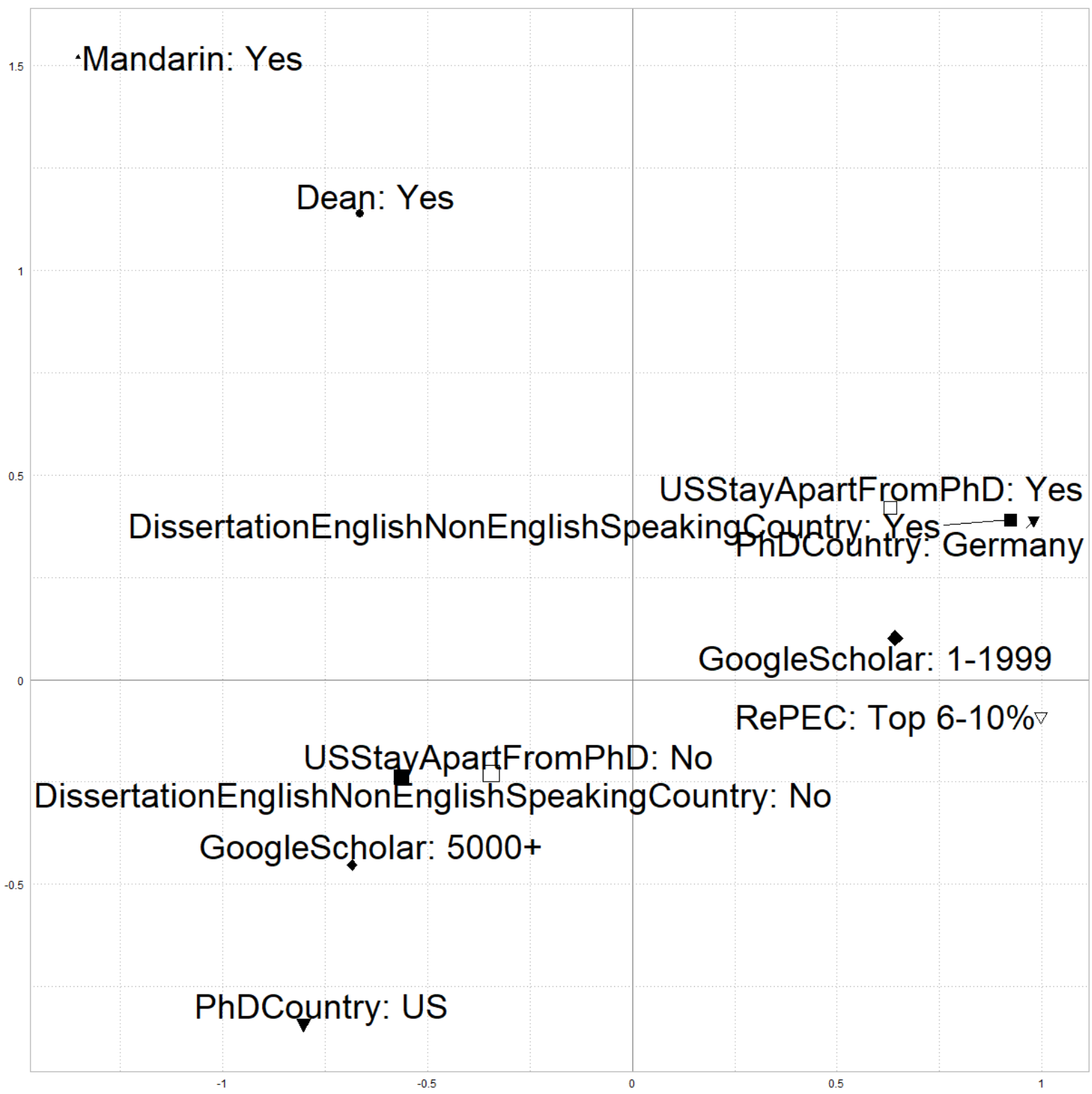

Notes: Left of the space: Academic capital, high volume of scientific capital and PhD in the US. Right of the space: Medium-range volume of scientific capital, English-speaking PhD in Germany and non-PhD stay in the US. 
Figure 6: Space of the professors of economics in 2017 (n=232), Cloud of modalities (axis 3; axis 1 on ordinate)

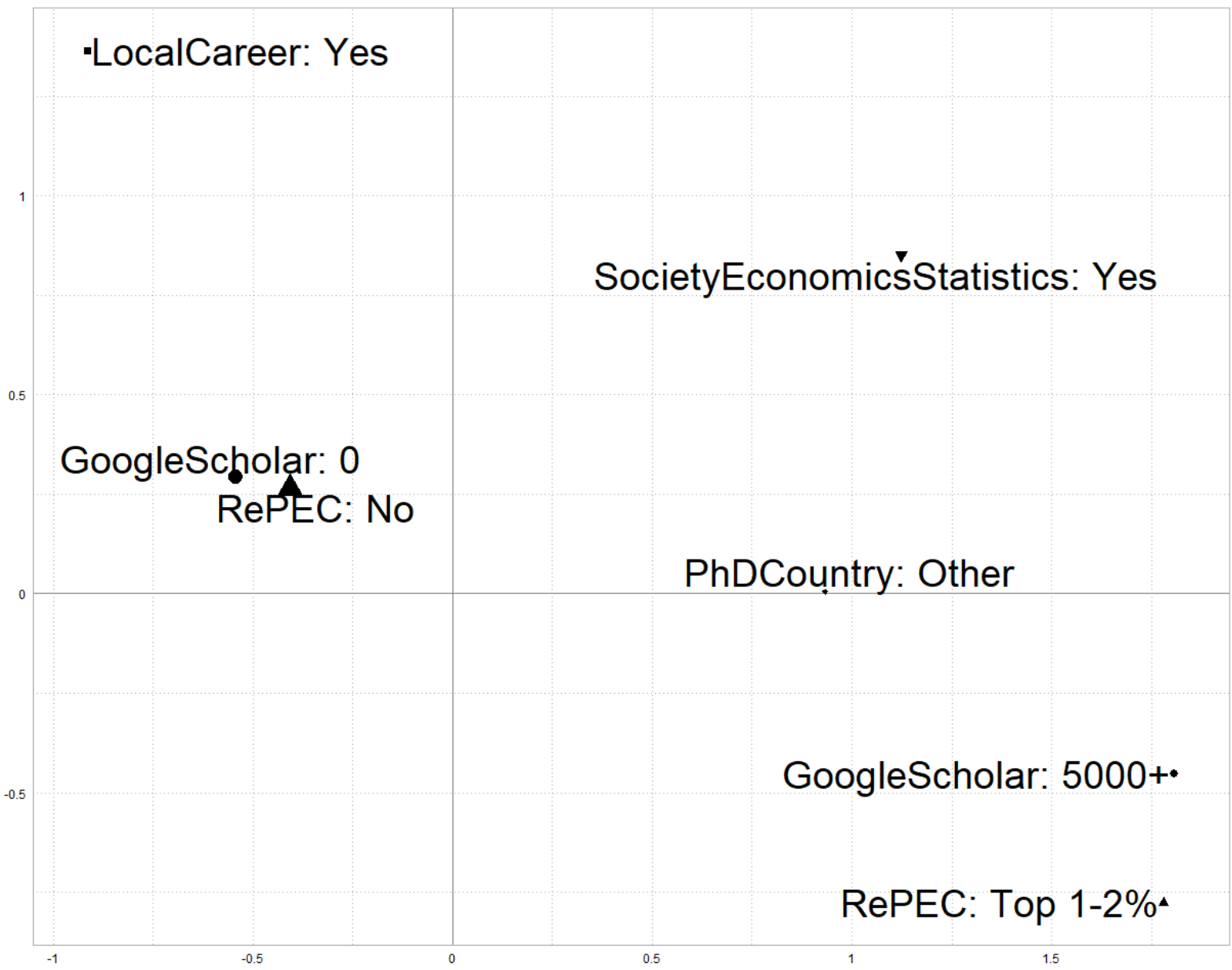

Notes: Left of the space: Local capital and a low volume of scientific capital. Right of the space: International capital and a high volume of scientific capital.

In a second step, I worked on subgroups profiles to uncover inequalities of resources within the field according to the sex and citizenship of the individuals. I divide them according to two illustrative variables: gender (men $n=209$ and women $n=23$ ) and citizenship (Swiss $n=74$ and non-Swiss $\mathrm{n}=158$ citizens at birth). Table 2 shows the association (through cosines and correlation coefficients) between the three axes of the MCA and the axes of the CSA of those groups ${ }^{18}$.

\footnotetext{
${ }^{18}$ According to the modified inertia rates for each level of variable, I retain two axes for the categories "woman" and "Swiss", and three for the categories "man" and "non-Swiss". The graphs for the levels of variables contributing above the average contribution for each of these CSA axes are displayed in appendix and must be read again from left to right.
} 
Table 2: Class-specific analyses of women, men, Swiss, and non-Swiss professors as illustrative variables: Cosines (correlation coefficients in parenthesis)

\begin{tabular}{|c|c|c|c|}
\hline & MCA 1 & MCA 2 & MCA 3 \\
\hline \multicolumn{4}{|c|}{ Women $(2$ axes $=89.1 \%)$} \\
\hline CSA 1 & $15.0(0.97)$ & $124.5(-0.57)$ & $76.5(0.30)$ \\
\hline CSA 2 & $76.8(0.23)$ & $43.6(0.72)$ & $61.8(0.60)$ \\
\hline \multicolumn{4}{|c|}{ Men $(3$ axes $=86.4 \%)$} \\
\hline CSA 1 & $164.3(-0.96)$ & $106.8(-0.29)$ & $81.2(0.15)$ \\
\hline CSA 2 & $75.7(0.25)$ & $158.1(-0.93)$ & $78.6(0.20)$ \\
\hline CSA 3 & $86.4(0.06)$ & $77.8(0.21)$ & $16.5(0.96)$ \\
\hline \multicolumn{4}{|c|}{ Swiss citizen at birth ( 2 axes $=82.9 \%$ ) } \\
\hline CSA 1 & $37.8(0.92)$ & $131.8(-0.67)$ & $92.7(-0.05)$ \\
\hline CSA 2 & $82.0(0.16)$ & $72.0(0.31)$ & $36.5(0.81)$ \\
\hline \multicolumn{4}{|c|}{ Non-Swiss citizen at birth ( 3 axes $=80.5 \%$ ) } \\
\hline CSA 1 & $48.9(0.71)$ & $33.8(0.83)$ & $89.3(0.01)$ \\
\hline CSA 2 & $92.4(-0.05)$ & $92.2(-0.04)$ & $28.5(0.88)$ \\
\hline CSA 3 & $95.2(-0.10)$ & $83.9(0.11)$ & $89.3(0.01)$ \\
\hline
\end{tabular}

Notes: Cosines and correlation coefficients give the same information. Correlation coefficients are standardized between -1 and 1 , where -1 is a perfect negative association, 1 a perfect positive association and 0 no association at all. For cosines, 0 shows a perfect positive association, 180 a perfect negative association, and 90 no association whatsoever. Strong associations are in bold characters. The percentage next to the number of axes is the percentage of cumulated modified rates they account for.

Only $10 \%$ of the professors in 2017 are women and the logics of oppositions of capitals are particularly male-centred (i.e. the axes of the MCA and the CSA for men show almost exactly the same properties). However, the structure of axes of the CSA is quite different for women, in particular if we look at the contributing levels of variables (in appendix). Axis 1 of the CSA builds along the volume of resources, based essentially on Swiss institutions of particularly important external power (academic organisations, faculty dean, expert committees), without the scientific capital component identified earlier. Women do not distinguish themselves according to important scientific assets $v s$. important external resources as the primary source of distinction within the field, but rather oppose between those who detain massive amount of capitals external to the field to those who do not. Axis 2 is organised around an opposition along the volume of scientific capital as well as different national sources of international resources. It is very similar to the second axis of the MCA, except that the volume of scientific capital does not opposes a high $v s$. a low volume, but rather a relatively low volume $v s$. the absence of it. This structure in two axes suggests that women do not strongly differentiate themselves according to scientific logics, mainly because they do not detain a large amount of this type of capital, and occupy from this point of view dominated positions when compared to $\operatorname{men}^{19}$.

The CSA on the Swiss professors shows that the two retained axes relate to the volume of resources. Axis 1 mainly corresponds to an opposition among the volume of external resources (academic organisations, corporations, expert committees, deanships), while Axis 2 opposes high volumes of resources related to the same institutions and high volumes of scientific resources (through Google Scholar and RePEc ranking) to the absence of these

\footnotetext{
${ }^{19}$ This use of CSA is part of an ongoing collaboration with Cléo Chassonnery-Zaïgouche (University of Cambridge) on a comparative perspective between women and men professors in Switzerland.
} 
resources. For the non-Swiss professors, Axis 1 and Axis 2 relate to a combination of diverse indicators of the volume of scientific resources (again through Google Scholar and the RePEc ranking), meanwhile Axis 3 mainly represents an opposition linked to the country of the $\mathrm{PhD}$ (see Appendix for more details). Swiss professors are much more invested in worldly logics related to (Swiss) institutions of power, while non-Swiss professors in Switzerland follow much more scientific logics.

MCA has been developed in social sciences in accordance with Bourdieu's programme to study field structure by spatializing individuals' position and position-takings on the basis of their capitals. Nonetheless, new features of MCAs can be useful to add new theoretical and methodological developments to Bourdieu's analyses. The study of subgroups within fields can be made by cluster analysis and CSA. In particular, CSA allows looking at the structure of capitals within a subspace of the field and characterizing it thoroughly, and has not been widely used until now. It could help studying differences in the uses of capitals, as well as their unequal distribution among different groups ${ }^{20}$. This could address new interrogations related to inequalities based on social properties, linking Bourdieusian methodology to other disciplines, such as gender ${ }^{21}$ or postcolonial studies.

\subsection{Sequence Analysis and Life Course Trajectories of Accumulation and Conversion of Capitals}

Another focus on Bourdieu's theoretical framework can be realised through the analysis of life course trajectories. Bourdieu did not focus on individual career histories at the aggregate level, since he relied more on a "snapshot" approach (Toft, 2018a). Nonetheless, working on the dynamics of fields, habitus, and capitals constitutes a promising development of his theory. In this sense, sequence analysis constitutes a relevant method, since it allows to work on timing, ordering, and duration of sequences of life course trajectories.

Sequence analysis (SA) is the statistical study of states or events. It consists in the comparison between chronological sequences of states, which can be characterized according to their similarities and dissimilarities (Abbott and Hrycak, 1990). Within a sequence, a time unit (a year, a month, an age, etc.) is attributed to states. Through an optimal matching algorithm, SA measures the degree of similarity of sequences taken two by two and a metric distance is created, which attributes costs following the number of operations to transform a sequence into another. Three operations are possible for these transformations: insertion (a state is inserted within the sequence), deletion (a state is deleted), substitution (a state is substituted by another). The higher the costs, the more the sequences will be dissimilar. Each substitution

20 Bourdieu (1984) thematised the volume and composition of capitals, but also a "third" dimension, corresponding to the evolution across time of this volume and composition. CSA can in fact help studying this evolution and, thus, field "history". Indeed, by performing MCA on individuals evolving at different periods in time, and by thereafter performing CSA on cohort variables, it is possible to compare the oppositions of capitals at different periods. I have presented my first results on the evolution of the capital composition between 1980 and 2000 under the title "Forms of Social Capital in the Field of Economists. Between Scientific and Worldly Power" (co-authored with Pierre Benz, University of Lausanne) at the "Forms of Power in Economics: New Perspectives for the Social Studies of Economics between Networks, Discourses and Fields" conference at the University of Giessen (December $6^{\text {th }}$ and $7^{\text {th }} 2018$ ). This communication will be part of a forthcoming collective book on the power of the economists for which I will be a co-editor.

${ }^{21}$ See Hjellbrekke and Korsnes (2016) using CSA to study women's capitals in the field of power in Norway. 
operation can be associated with a cost, which can be either constant, or theoretically or empirically defined (Gauthier et alii., 2014). Once these costs established, a form of automatic classification, generally a hierarchical clustering, is used. It consists in grouping similar sequences in homogenous groups, which differ from one another the most (MacIndoe and Abbot, 2004). The number of clusters can be chosen empirically or by using a variety of indicators of fit (Studer, 2012). In sociology, SA is useful to compare trajectories regarding particular attributes along the life course of a given group of individuals.

Combining SA with Bourdieu's framework is possible by conceptualising it through a more biographical approach. A particular habitus cannot be understood without thinking in terms of temporality: to become a "structured structure", individuals' socialisation takes time, and habitus is therefore a by-product of an individual and a collective "history" (Bourdieu, 1990). Capitals are involved in long-term processes of accumulation and conversion (Bourdieu, 1986), and social trajectories are understood as the succession of positions in the successive states of the field(s) within which individuals evolve (Bourdieu, 1994: 88). Capitals acquired or inherited in particular fields can be accumulated over time. This accumulation provides advantage within a given field. Moreover, capitals can be converted into other capitals with influence in other fields (Savage et alii., 2005). Life courses can be conceptualised as movements through social space and through participations in several fields. Positional changes within a specific field tend to correspond to slow and continuous accumulation processes, while changes from one field to another are often related to more or less rapid processes of conversion of one capital into another, which are likely to be more fundamental on the level of the subjective experience of individuals (Levy and Bühlmann, 2016). Across the various positions occupied within the social space, measured through a specific state in $\mathrm{SA}$, is attached a certain type and volume of capitals, which can be accumulated and, at a certain point and under certain conditions, converted. SA provides the possibility to investigate the structure of acquisition, accumulation, and conversion of various capitals and is in this sense much richer than displaying the volume and structure of capitals in an ahistorical manner, as basic features of MCA do. SA allows to work on the comparison of diverse trajectories of accumulation and conversion of capitals ${ }^{22}$.

I give a quick example stemming from my $\mathrm{PhD}$ data. I focus on the academic paths of accession to a professor position between the age of 21 and $50^{23}$ for professors of economics and business at the dates of 1957, 1980 and 2000. To do so, I coded six states, which are strictly exclusive from one another: 1) A period of education, which is covered from the age of 21 until the age of the doctorate; 2) Extra-academic positions, associated mostly with professional occupations in the private sector and the state administration, which relate to forms of capitals which are external to the field; 3) Postdoctoral positions: pre-tenured positions between the end of the educational period and the appointment to a professor position, which represents the "lowest" volume of resources within academia; 4) Associate

\footnotetext{
${ }^{22}$ Occurrences of use of SA within Bourdieu's framework are, amongst others: Bühlmann, 2008, 2010; Toft, 2018a, 2018b, 2019; Araujo, 2018; Ellersgaard et al. 2019.

${ }^{23}$ This choice of taking the ages of professors as a time-unit implies considering individuals at a biographical level. Analyses are not focusing on the historical evolution and transformations in the structure of careers within the field, but rather on the trajectories of accumulation and conversion of capitals during the life course of individuals who, at some point in history, occupy a position within this field. To focus on field history, one must instead choose the calendar year as a time-unit.
} 
professor positions: the "lower" form within the symbolic hierarchy of professor positions; 5) Full professor positions: the higher form of symbolic resources within this hierarchy; 6) Institutional executive positions within universities and other academic societies, associated with academic power resources. After having used a substitution-cost matrix determined theoretically, I ran a hierarchical cluster analysis using a Ward criterion. I chose then empirically a partition into four clusters ${ }^{24}$. Each cluster corresponds to a particular path of accumulation and conversion of capitals within (and sometimes outside) academia. The clusters are represented in Figure 7. These typologies allow me to answer the question of how the professional trajectories of economic sciences professors are structured in terms of accumulation and conversion of capitals ${ }^{25}$.

\footnotetext{
${ }^{24}$ Analyses were performed through the TraMineR package in $R$ (Gabadinho et alii., 2011).

${ }^{25}$ These results were presented under the title "Pathways to Professorships in Swiss Economics and Business Studies Departments since the 1950s. The Importance of Scientific, International and Social Capitals", at the $5^{\text {th }}$ annual conference of the Society for the History of Recent Social Science, University of Zurich, June 8-9 2018. They are part of an ongoing work on the different academic pathways to accede to a professor position in the Swiss context of economics and business studies.
} 
Figure 7: Clusters of economic sciences professors' careers for the three cohorts of 1957, 1980 and $2000(n=411)$
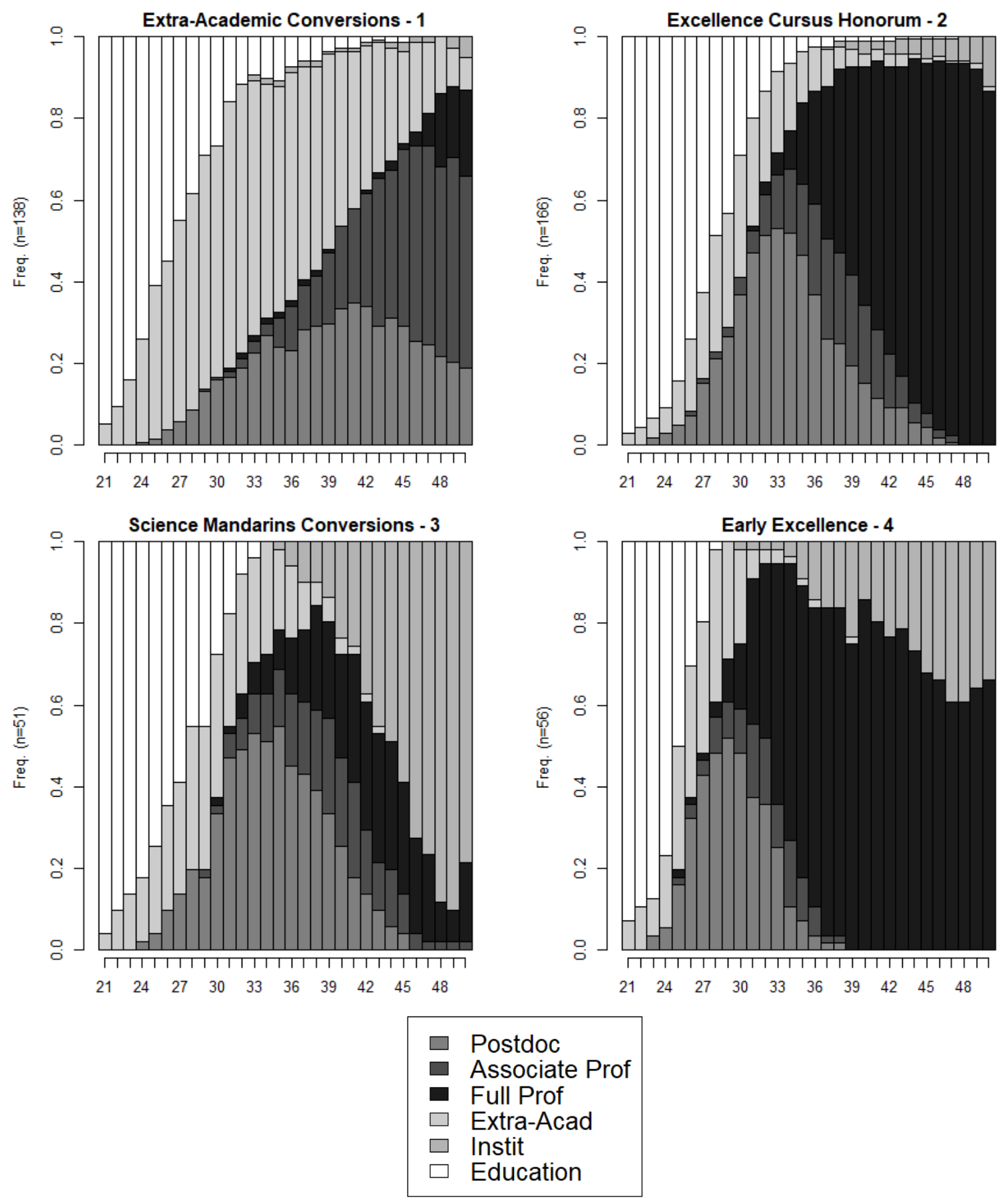

Note: $X$ axis displays age between 21 and 50 years old. $Y$ axis displays frequencies.

Extra-academic conversions trajectories $(\mathrm{n}=138)$ display accumulation of extra-academic resources in the early professional trajectory, and only late conversions into associate professor positions. These are mostly the careers of "practitioners", who are able to convert these external resources into an academic ones, but only associated with a medium-level volume of academic capitals. Excellence cursus honorum careers $(\mathrm{n}=166)$ correspond to a much more "linear" path to become a professor, with postdoctoral positions until the thirties, a relatively short time-period of associate professor and a long time as full professor. These 
trajectories are associated with a process of long-term, but steady, accumulation of academic resources, which are highly valued on a symbolic level, and are deemed "excellent" academic careers. Science mandarins conversions $(\mathrm{n}=51)$ correspond to similar beginning of careers to the precedent cluster until the full professor appointment. What changes is that these professors are able to convert the academic resources they have accumulated into academic institutional positions. They are without a doubt part of the group of professors with a very high influence outside the economic sciences field, leading science policy in Switzerland. Finally, Early excellence careers $(\mathrm{n}=56)$ correspond to the quickest accumulation of academic resources and full professor appointment. Also, to some extent, they are able to convert these rapidly accumulated assets into academic executive resources and sit on important academic boards.

SA is useful to study timing, order, and duration of different sequences of states. This method provides the possibility to study individual trajectories of accumulation and conversion of capitals in relation to one another, which provides much richer information than studying temporally "flattened" configurations of capitals trough basic a-historical features of $\mathrm{MCA}^{26}$. However, these two methods have to be considered as complementing one another. One of the main limitation to SA is that it does not take into account the ways in which careers are located in the spatial social structure (Abbott, 2001: 123). The most fruitful strategy would be to combine both of these methods, for example by projecting typologies of sequences into MCA to assess the relevance of adding life-course to a space of "snapshots" of positions, considering career structures as a particular resource within a social space (Toft, 2019). One must also note that, like MCA, it is also possible to work on subgroups through SA, either by identifying typologies of careers through clustering, as done here, or by working on subspaces defined on the basis of particular properties (e.g. careers of men vs. careers of women).

\subsection{Social Network Analysis and Social Capital}

Despite having dedicated almost his entire work to the relations and differences among social groups, Bourdieu's works on the ties between these groups understood as power resources, or said otherwise on social capital, remain very scarce (the main exceptions of conceptualisation of social capital being: Bourdieu, 1980, 1986). Nonetheless, during these last few years, some scholars have tried to operationalize Bourdieu's work on social capital through network approaches. Here I present social network analysis (SNA), possible bridges with Bourdieu, and an example of my research.

SNA is a relational method that studies ties between either individuals or institutions (onemode networks), or both at the same time (two-mode networks). SNA can help us studying the position of an individual in a network, which is not (necessarily) based upon geometrical distances, but on links between the whole group of individuals. Graphically, networks are

\footnotetext{
${ }^{26}$ Further developments of MCA allow studying temporality in fields based on individual careers. Indeed, to work on oppositions of capitals within the same group of individuals during more than one time-period, one can use multiple factor analysis, by conducting several MCAs, each on a different period, then reuniting the different coordinates of individuals and performing a principal component analysis on these coordinates by weighting them through the variance of their first axis. It is thus possible to visualise the structure of individual lives at different time-periods in the same space (Rossier and Fillieule, 2019; Robette and Roueff, 2017; Mercklé, 2017).
} 
represented by "edges" (ties) between "nodes" (individuals or organizations). Edges can be undirected or directed. A "structural" network is delimitated through more or less institutionalised social boundaries and represented in its entirety. An "ego-network" corresponds to individuals linked to a particular individual (or institutions linked to a particular institution). Graphs in SNA allow a visual interpretation of the data, by observing the structure, density, and dispersion of the ties. To be read more easily, graphs are often dispersed according to spatialisation algorithms, which generally minimize the variance of the edges, while trying to avoid that edges cross each other, and that nodes overlap. To investigate in more detail the structure of the network, indicators of density are available and, at the individual level, indicators of node centrality. To study subgroups, several algorithms allow identifying subcomponents (clusters, cliques, k-cores, etc.) (Borgatti et alii., 2013; de Nooy et alii., 2018; Mercklé, 2011; Godechot, 2010). SNA is useful for studying the configuration of a particular form of capital developed, among others, by Bourdieu: social capital.

Bourdieu always encouraged the use of MCA as a relational method (see Bourdieu and Wacquant, 1992: 96-97) and, by doing so, rejected other relational methods such as SNA (de Nooy, 2003: 306). Nonetheless, his concern was more with the kind of relationship studied than with the method. SNA, when studying Bourdieu's account of social capital ${ }^{27}$, should focus on objective relations, i.e. power relations within a space structured by the possession of capitals, rather than interpersonal or intersubjective relations, usually studied with this method (de Nooy, 2003). In Bourdieu's sense, social capital needs to be considered in relation with the volume of other individuals' resources (economic, cultural, symbolic, specific, and social capitals), and can be considered as a form of symbolic capital as well, since having a large volume of network relations also leads to "prestige" (Denord, 2015). The volume of social capital of an individual depends on the size of his/her network and on the volume of other capitals detained by each agent he/she is connected to (Bühlmann et alii., 2018). A large volume of well configured social capital provides an individual with a favourable position within a given field. SNA is a complementary tool to MCA since it focuses on existing objective links of mutual acquaintance and recognition and not on relations between individuals within a given volume and structure of capitals. Some scholars (Bühlmann et alii., 2012a; Timans and Heilbron, 2018; Eloire, 2018; Klüger, 2018) encourage a joint use of both methods.

I provide an example from my work: the network of co-applications for projects funded by the Swiss National Science Foundation (SNSF) ${ }^{28}$ of economic sciences professors in $2000^{29}$. The

\footnotetext{
${ }^{27}$ Social capital understood as a resource has been widely studied. It has been understood as a source of social coordination and integration (Coleman, 1990) or, as inspired by Granovetter (1973), in terms of networks structures and assets, where the importance of this resource depends on the relative centrality of individual position. Lin (2001) develops and systematizes a theory of social resources based on Granovetter's distinction of strong and weak ties, meanwhile Burt (1992) gives importance on the exclusivity of a position in a network based on information access, control or diffusion. In this latter model, individuals can take advantage of "structural holes", understood as positions which control and mediate information between two otherwise unconnected network components (see: Denord et al., 2011; Mercklé, 2011: 42-55). Different uses of centrality indicators stem from these diverse understandings of social capital as an (individual or collective) resource. I focus on Bourdieu's understanding of social capital, but nevertheless acknowledge other acceptations of the concept as a contribution to Bourdieu's relational sociology, which guide the use of different centrality measures understood as different forms of social capital.

${ }^{28}$ The data stem from the SNSF "P3" database: http://p3.snf.ch/.
} 
link between individuals is defined by having jointly been funded for a research project, which leads to a one-to-four-year research collaboration, on average. This link is an institutional link, which formalizes a more or less close relation of acquaintance and joint scientific practice. I investigate three particular forms of social capital within the field of economic sciences, to assess individuals' centrality and quality of resources, and influence within the field understood as a network of relations. First, interdisciplinarity can be associated with the specific capital of the field. A large level of interdisciplinarity must be contrasted with a lower level and gives information on the composition of the ego-network of each professor, in terms of the particular qualities detained by other individuals he or she is connected to. Second, the absolute number of individuals connected to the professors gives information on the size of an individual network and constitutes a raw quantitative measure of an individual's social capital. Third, the more or less favourable position in the network gives information on the number of individuals more or less directly connected to a professor's personal network, e.g. in terms of being on the shortest paths between a pair of individuals, providing insights on the influence of each professor. Figure 8 represents the size of the network by degree ${ }^{30}$ centrality, and Figure 9 represents the position in the network by betweenness ${ }^{31}$ centrality. Disciplines are represented by the colours of the nodes. However, since visualization in networks cannot work as proofs (Lemercier, 2005), I focus on a small group within the network, i.e. the ten most central professors according to degree and betweenness centrality (Table 3 and 4). This allows me to work on the particular profile of individuals with a high volume of social capital, while considering some of their social properties $^{32}$, focusing on some features of the structure of social capital within the field.

\footnotetext{
${ }^{29}$ The network is composed of 1672 ties between 751 individual nodes. Among them, 156 professors (out of 261) of economics and business studies in 2000 have at least one tie. The 105 other professors are not represented in the graphs.

${ }^{30}$ An indicator of centrality, which corresponds to the number of nodes with which a given node is connected to.

${ }^{31}$ Another indicator of centrality, based on how often a given node falls on the shortest path between two other nodes. The position within the network can be assessed by a range of other centrality indicators as well.

${ }^{32}$ Sex, university of teaching, discipline, teaching topic, number of research projects obtained through the SNSF, money granted through these projects, and interdisciplinary rate (i.e. percentage of researchers from another discipline - including economics for business scientists, and business studies for economists - in their personal network). To better assess degree centrality, I give information on the weighted degree, here the total number of scientific collaborations, independently of the number of other individuals connected to a professor.
} 
Figure 8: Network ${ }^{33}$ of co-applications of SNSF research projects of economic sciences professors in 2000: Size of the nodes by degree centrality

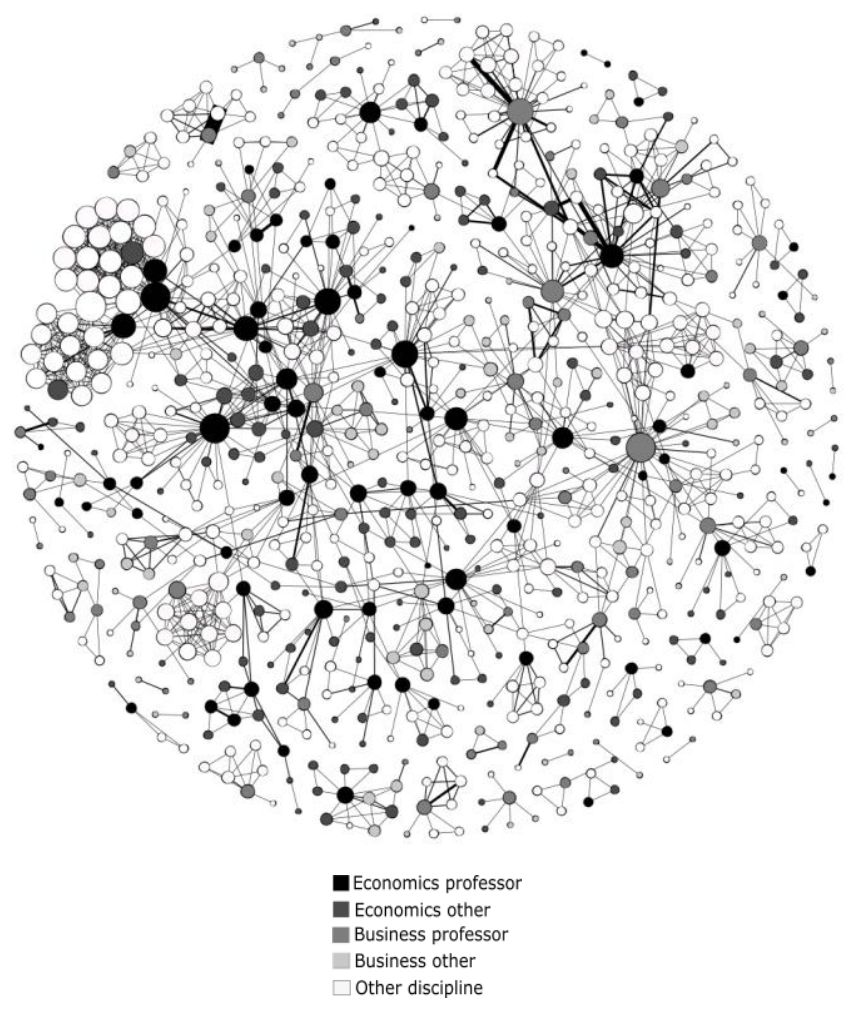

Table 3: Ten most central individuals in the network of co-applications of SNSF research projects of economic sciences professors in 2000, by degree centrality ${ }^{34}$

\begin{tabular}{|c|c|c|c|c|c|c|c|c|c|c|}
\hline Last name & First name & Sex & University & Discipline & Teaching topic & $\begin{array}{l}\text { Number } \\
\text { projects }\end{array}$ & Swiss Francs (M) & Degree & $\begin{array}{l}\text { Weighted } \\
\text { degree }\end{array}$ & $\begin{array}{l}\text { Interdisciplinarity } \\
\text { rate }\end{array}$ \\
\hline Flückiger & Yves & Man & Geneva & Economics & Labour economics & 13 & 1.74 & 31 & 36 & $81 \%$ \\
\hline Holly & Alberto & Man & Lausanne & Economics & Econometrics & 21 & 8.95 & 31 & 39 & $45 \%$ \\
\hline Schmid & Beat Friedrich & Man & St.Gallen & Business & Business informatics & 18 & 5.67 & 31 & 34 & $81 \%$ \\
\hline Leu & Robert E. & Man & Bern & Economics & Economic policy & 20 & 6.40 & 26 & 33 & $50 \%$ \\
\hline Carlevaro & Fabrizio & Man & Geneva & Economics & Econometrics & 14 & 2.27 & 26 & 33 & $46 \%$ \\
\hline Pellegrini & Christian & Man & Geneva & Business & Business informatics & 41 & 6.56 & 26 & 68 & $92 \%$ \\
\hline Ritschard & Gilbert & Man & Geneva & Economics & Econometrics & 10 & 2.20 & 23 & 30 & $91 \%$ \\
\hline Antille Gaillard & Gabrielle & Woman & Geneva & Economics & Applied economics & 17 & 2.25 & 22 & 39 & $68 \%$ \\
\hline Sheldon & George & Man & Basel & Economics & Applied economics & 8 & 0.69 & 20 & 21 & $85 \%$ \\
\hline Maillat & Denis & Man & Neuchâtel & Economics & Applied economics & 26 & 2.67 & 20 & 52 & $65 \%$ \\
\hline
\end{tabular}

By looking at some properties of the ten most central professors according to degree centrality (Table 3), i.e. the ones endowed with the highest volume of social capital from the viewpoint of direct ties to a large number of other researchers, one sees that they largely consist of men (only one woman), that they mostly teach in French-speaking universities (seven teach in Geneva, Lausanne or Neuchâtel) and that they are mostly economists (only 2 are business scientists). In business studies, the more connected professors teach business informatics. These latter professors are particularly interdisciplinary ( $81 \%$ and $92 \%$ of their collaborators, and actually mostly collaborate with computer scientists), detaining a particularly heteronomous form of social capital. To the contrary, two of the three econometricians (Holly

\footnotetext{
${ }^{33}$ The nodes are spatialized through the Fruchterman and Reingold algorithm, thanks to the Gephi software (Bastian et alii., 2009).

${ }^{34}$ To be more readable, I did not include the names of the individuals in Figures 8 and 9, but they are available upon request to the author.
} 
and Carlevaro) have the highest disciplinary ratio of the whole group (more than half of their network is composed of economists). Some, as the business scientist C. Pellegrini, have obtained a very large number of projects compared to the others (41), involving a very large amount of money as well (6.56 million CHF - only A. Holly obtained more than this amount: 8.95 million), and have collaborated much more than once with the same group of peoples (68 collaborations in total within a group of 26 researchers). This type of researchers shows a particularly tightly interconnected personal network and an intensive research practice, with several collaborations with the same people. Others, such as the Basel professor G. Sheldon, only have obtained a low number of projects (8) with a lower amount of money ("only" 0.69 millions), and, despite being tied to an almost as large number of researchers as Holly (20), have collaborated with them, with one exception (weighted degree $=21$ ), only once. Degree centrality constitutes a relevant first indicator to map the structure and inequalities of social capital within a field.

Figure 9: Network of co-applications of SNSF research projects of economics sciences professors in 2000: Size of the nodes by betweenness centrality (standardised between 0 and 1)

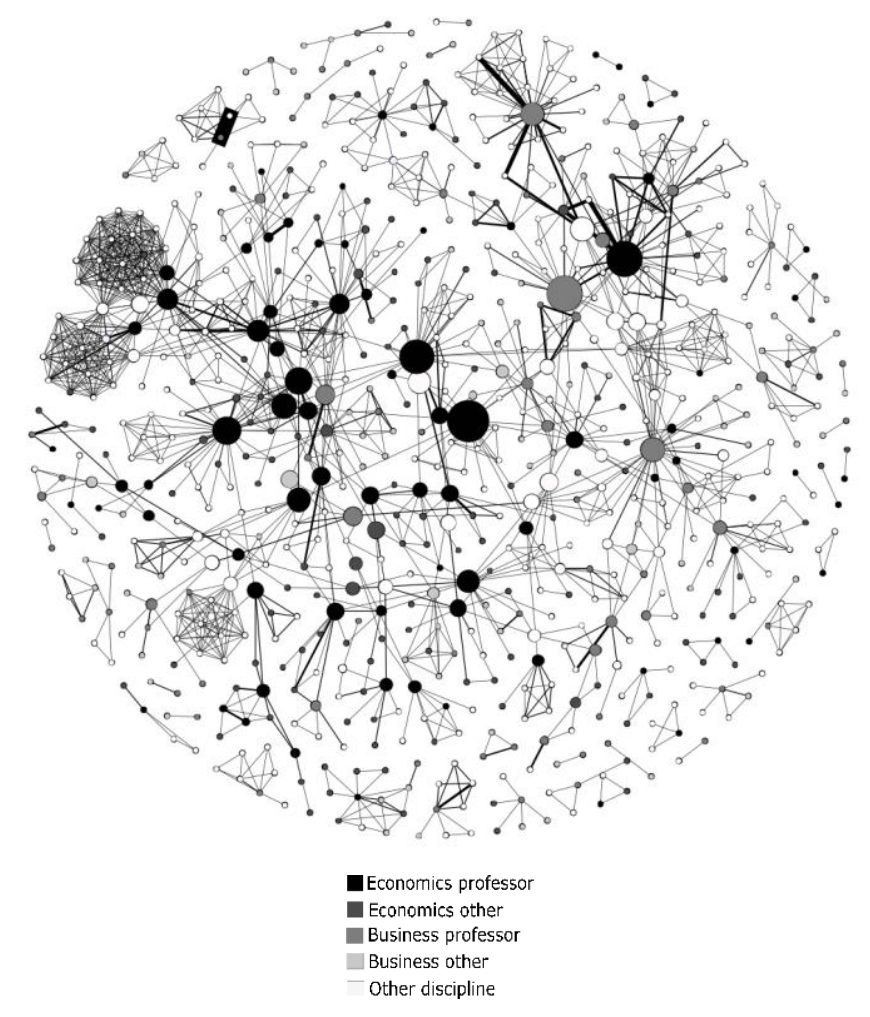


Table 4: Ten most central individuals in the network of co-applications of SNSF research projects of economic sciences professors in 2000, by betweenness centrality

\begin{tabular}{|c|c|c|c|c|c|c|c|c|c|}
\hline Last Name & First Name & Sex & University & Discipline & Teaching topic & $\begin{array}{l}\text { Number } \\
\text { projects }\end{array}$ & $\begin{array}{l}\text { Swiss Francs } \\
\text { (M) }\end{array}$ & Betweenness & $\begin{array}{l}\text { Interdisciplinarity } \\
\text { rate }\end{array}$ \\
\hline Jeanrenaud & Claude & Man & Neuchâtel & Economics & Economic policy & 17 & 3.57 & 0.20 & $68 \%$ \\
\hline Perret & Francis-Luc & Man & Lausanne Inst. of technology & Business & Management & 15 & 3.32 & 0.15 & $89 \%$ \\
\hline Maillat & Denis & Man & Neuchâtel & Economics & Applied economics & 26 & 2.67 & 0.15 & $65 \%$ \\
\hline Leu & Robert E. & Man & Bern & Economics & Economic policy & 20 & 6.40 & 0.14 & $50 \%$ \\
\hline Holly & Alberto & Man & Lausanne & Economics & Econometrics & 21 & 8.95 & 0.09 & $45 \%$ \\
\hline Krishnakumar & Jayalakshmi & Woman & Geneva & Economics & Econometrics & 14 & 2.28 & 0.09 & $13 \%$ \\
\hline Zarin-Nejadan & Milad & Man & Neuchâtel & Economics & Economic policy & 6 & 1.38 & 0.07 & $22 \%$ \\
\hline Soguel & Nils & Man & Lausanne & Economics & Economic policy & 7 & 1.30 & 0.07 & $78 \%$ \\
\hline Pellegrini & Christian & Man & Geneva & Business & Business informatics & 41 & 6.56 & 0.06 & $92 \%$ \\
\hline
\end{tabular}

When looking at the ten most central individuals in the network according to betweenness centrality (Table 4), one sees that half of them are also present in the top 10 professors by degree centrality ${ }^{35}$. Nonetheless, interesting insights about this indicator are worth mentioning, since they represent the professors most endowed with social capital in the form of the number of times they fall on the shortest path between two nodes, giving information on these professor's favourable position within the network. As for the former indicator, they are most of all composed of men (9), French-speaking professors (8), and economists (7). Pellegrini, who was well-doted in social capital in terms of degree, with a large number of collaborators, ties and money, falls less within the shortest paths than others in this group, having a less favourable position within the network. To the contrary, a professor such as $\mathrm{C}$. Jeanrenaud from Neuchâtel is the most well-situated according to this indicator, despite having a smaller degree (19), fewer projects (17) and less money (3.57 millions). He has a valuable resource, which is related to his ability to often connect two unconnected individuals. It is also worth noting that in this group, two professors, J. Krishnakumar and M. ZarinNejadan, do not value interdisciplinary connections (resp. only $13 \%$ and $22 \%$ of their collaborators are from another discipline), but they counter-balance this particular disciplinarity by occupying a favourable position and being connected to individuals who are themselves connected to researchers from other disciplines. Betweenness centrality also reveals individuals endowed unequally with social capital.

Contrary to the two previous methods, SNA permits the study of the configuration of a particular capital, namely social capital. It is possible to investigate particular features of individual networks, among others their composition (the volume and nature of capitals of individuals in their direct network), their size (the absolute number of individuals in their network) and their position (as more or less favourable).

\section{Using Prosopography and Relational Methods to study the Rise and Transformations of Economics and Business Studies in Switzerland}

In this penultimate section, I summarize more precisely the outline of my doctoral dissertation, as well as its main questions, arguments and findings. I stress how the combinations of a prosopographical strategy and use of the relational methods developed in this paper helped me to obtain these results. As stated above, I studied the structure of the

\footnotetext{
${ }^{35}$ Pearson's $r$ between degree and betweenness centrality equals to $0.73^{* * *}$ here.
} 
scientific field of economic sciences, divided into economics and business studies in Switzerland, focusing on university professors. I asked two global research questions: 1) How did economic sciences professors acquire power and influence in Swiss universities, as well as in the state and the private sector? 2) How was the space of economic sciences professors structured according to autonomous and external logics, and how did this structure change during the $20^{\text {th }}$ century? To answer these questions, my dissertation was divided into four main chapters.

A first chapter focused on the rise of economic sciences in the Swiss academic field (i.e. the field of Swiss universities). Having followed a thorough prosopographical strategy on all university professors in economics and business studies from 1819 onwards, as well as other archival research on universities, I detailed the numerical increase of students and academic personnel compared to other disciplines and the institutional (professorial chairs, diplomas, and creations of institutes and departments) and disciplinary (creation of associations and journals) affirmation of economics and business studies through descriptive statistics. I showed that professors of economic sciences have been able to accumulate a very large amount of capital of academic power, which relates to executive positions of power in academic institutions. As an example, in the recent period, economic sciences were the most represented among university vice chancellors (rectors).

A second chapter was centred on these professors' place in the field of power, and as occupying elite positions in the political (national elected officials), economic (CEOs and board members of large corporations) and administrative (federal senior civil servants) fields. Again, I collected biographical data and relied on already available data on Swiss elites, thanks to former research projects. I investigated the profile of the professors occupying such positions, the structure of their academic and extra-academic careers, and their indirect social capital through $\mathrm{PhD}$ supervision of future elite members. I showed that among university professors members of Swiss elites during the recent period, economic sciences were the first discipline represented among economic elites, and the second among political and administrative elites, after law. I also showed a clear separation between "pure" academic careers, and careers partially turned towards extra-academic positions, and the persistence of this separation over time, thanks to sequence analysis.

A third chapter focused on the international dimension of Swiss economic sciences. It studied the distribution of professors through Swiss or foreign citizenship, as well as professional stays abroad, as a doctoral or postdoctoral researcher, or as a professor. The structure of the careers at the national and international level were investigated, in particular by considering the international hierarchy of national spaces, where a stay in the more well-ranked NorthAmerican or British universities matters particularly. Sequence analysis helped to identify the more national professorial careers and the more international ones. International careers were put in relation to scientific capital, which was measured through citations in "prestigious" journals, using data of the Web of Science Social Sciences Citation Index. I showed that Swiss economic sciences experienced a process of "nationalization" of professor profiles after World War I, and of re-internationalization since the 1970s. I also observed that there was a significant association, from the Swiss viewpoint, between scientific capital and internationality, but also that a definitional shift of this link happened during the $20^{\text {th }}$ century, from stays in Germany and France to stays in the US. 
A fourth and final chapter focused on the structure (and evolution) of the space of economic sciences, and particularly on the space of positions of the professors related to the distribution of diverse capitals, as well as on their position-takings on several ways of doing science (use of mathematical abstraction and empirical methodology, specialization domain, inclination towards interdisciplinarity). To do so I used multiple correspondence analysis and social network analysis, which was useful to obtain an indicator of interdisciplinarity, by assessing the disciplines of all the scientists to whom a professor was connected through a network of scientific collaboration projects. Thanks to this methodology, I observed a clear opposition between a scientific and international pole, and a pole detaining most of all national resources, as well as capital of academic power, and economic and political capitals. The scientific pole increasingly used mathematics over times and each of the two poles had its own research areas. Dominance within the space, apart from using mathematical abstraction and the study of particular objects, was also reflected in a relatively sustained interdisciplinarity, particularly with the natural, experimental, technical, or medical sciences.

In conclusion, I argued that it is by this "division of labour" between two poles of professors, those linked to scientific and international "excellence" and those related to the administration of universities, corporations and the state, and by the historical strengthening this division, that economists and business scientists were able to be "everywhere" (Fourcade, 2009) and were able to reinforce their power in Swiss society.

\section{Conclusions}

In this article, I presented Bourdieu's research programme and its possible developments with the help of quantitative data analyses, exemplifying each method through some of my $\mathrm{PhD}$ work. In a part dedicated to data collection, I underlined the relevance of using a prosopographical strategy, in order to circumscribe individuals evolving in a field and gather systematic data on their properties, understood as different resources having influence in this given space, which allow studying its history and structure.

In the section on data analysis, I presented three methods in particular. 1) Multiple correspondence analysis has been used by Bourdieu and other researchers to study empirically the distribution of capitals in a given field, as well as the structural homology between positions and position-takings. I proposed, as a further development of MCA rarely (but with notable exceptions) undertaken, the study of subgroups within a field, through class specific MCA. 2) Sequence analysis allows working on accumulation and conversion of capitals during individual lives, with a specific focus on timing, order and duration of each state of capital detention in the sequence. To each state in a life course sequence corresponds a certain volume and type of capital, which can be accumulated and, under certain conditions, converted into another. Typologies of careers can be identified and it is possible to investigate subgroups' profile. 3) Social network analysis focuses on one particular capital, social capital, considered in relation with other individuals' capitals. In particular, at least three forms of social capital can be investigated: the composition of the network (i.e. the type and volume of capitals of the individuals directly connected to one individual network); the size of the network of an individual; the more or less favourable position of an individual within the structure of the network. 
I have addressed the issue of working on new methodological developments, which were not underlined by Bourdieu before his death, and also on new research questions, originating from other domains or disciplines, such as history, network sociology, life course sociology, gender studies, postcolonial studies, etc. As stated in the introduction, I argue that when introducing new quantitative methodology into Bourdieu's research programme (which should be - and indeed already is - undertaken by a large and dynamic community), we should think beyond Bourdieu's strict work, but still within his theoretical framework, which is relevant to the study of domination and power relations among individuals. I focused in this article on quantitative methods, but the exact same reflection might be true for qualitative analysis as well: ethnography, participant observation, interviews, analysis of historical documents, content analysis, and so on. Moreover, inter-operability between methods should also work between qualitative and quantitative analyses.

This paper only constitutes a partial panorama of quantitative methods to be used within Bourdieu's framework. Quantitative discourse analysis, to analyse discursive positiontakings, often by combining a Bourdieusian and a Foucauldian or a Wittgensteinian perspective (Schmidt-Wellenburg, 2018), has also proven relevant. Moreover, a technique, which was particularly distrusted by Bourdieu (Bourdieu and Darbel, 1966), corresponds to regression analysis. Regressions can nevertheless be useful to focus on associations and interactions between variables: e.g. to ascertain the interactions between social capital (as a dependent variable) and a set of different capitals (Bühlmann et alii., 2018), or the interactions between diverse components of scientific and international resources (Rossier and Bühlmann, 2018). Further methodological developments remain to be made with, rather than beyond, Bourdieu.

\section{Acknowledgments}

I am greatly indebted to both my PhD supervisors, André Mach and Felix Bühlmann, for the reflections that led to this article, and to the other members of my $\mathrm{PhD}$ committee: Frédéric Lebaron, Mikael Börjesson, Thomas David, and Franz Schultheis. This article is also tributary of long discussions with Pierre Benz, Pedro Araujo, and Kevin Toffel (I thank them in particular for their very helpful comments on an earlier version of the paper), as well as the other participants to the "Bourdieu" doctoral seminar held at the University of Lausanne in 2014-2017. Further thanks go to Olivier Fillieule for keeping the discussion going. Finally, I thank both the editors of the journal, Sophie Duchesne and Viviane le Hay, as well as both anonymous reviewers, for helping me improving this paper significantly. Further thanks go to Karl van Meter, for helping me improving my English in the last version of this paper.

\section{Declaration of Conflicting Interests}

The Author(s) declared no potential conflicts of interest with respect to the research, authorship, and/or publication of this article.

\section{Funding}

The authors received no financial support for the research, and/or publication of this article. 


\section{References}

Abbott A (2001) Time Matters. On Theory and Method. Chicago: University of Chicago Press.

Abbott A and Hrycak A (1990) Measuring Resemblance in Sequence Data: An Optimal Matching Analysis of Musicians' Careers. American Journal of Sociology 96(1): 144-185.

Araujo P (2018) Dynamics of internationalization. A sequential analysis of the careers of Swiss banking elites. In: Korsnes O, Heilbron J, Hjellbrekke J, Bühlmann F and Savage M (eds.) New Directions in Elite Studies, Oxford and New York: Routledge: 73-89.

Atkinson W (2016) Beyond Bourdieu. From Genetic Structuralism to Relational Phenomenology. Cambridge (etc.): Polity Press.

Bastian M, Heymann S and Jacomy M (2009) Gephi: An Open Source Software for Exploring and Manipulating Networks. AAAI Publications, Third International AAAI Conference on Weblogs and Social Media.

Blasius J, Lebaron F, Le Roux B and Schmitz A (eds.) (2019; forthcoming) Empirical Investigations of Social Space. Cham $(\mathrm{CH})$ : Springer.

Bonnet P, Lebaron F \& Le Roux B (2015) L'espace culturel des français. In: Lebaron F and Le Roux B (eds.) La méthodologie de Pierre Bourdieu en action. Espace culturel, espace social et analyse des données. Paris: Dunod: 99-130.

Borgatti SP, Everett MG and Johnson JC (2013) Analysing Social Networks. Los Angeles: SAGE Publications Ltd.

Bourdieu P (1962 [1958]) The Algerians, Boston: Beacon Press.

Bourdieu P (1980) Le capital social. Notes provisoires. Actes de la recherche en sciences sociales 31: 2-3.

Bourdieu P (1984 [1979]) Distinction: A Social Critique of the Judgement of Taste. Cambridge MA: Harvard University Press.

Bourdieu P (1986) The forms of capital. In: Richardson JG (ed.) Handbook of Theory and Research for the Sociology of Education. New York: Greenwood: 241-258.

Bourdieu P (1988 [1984]) Homo Academicus. Palo Alto CA: Stanford University Press.

Bourdieu P (1990 [1980]) The Logic of Practice. Palo Alto CA: Stanford University Press.

Bourdieu P (1994) Raisons pratiques. Sur la théorie de l'action. Paris: Editions du Seuil.

Bourdieu P (1996a [1992]) The Rules of Art: Genesis and Structure of the Literary Field. Palo Alto CA: Stanford University Press. 
Bourdieu P (1996b [1989]) The State Nobility. Elite Schools in the Field of Power. Cambridge: Polity Press; Oxford: Blackwell Pulishers Ltd.

Bourdieu P (2000 [1997]) Pascalian Meditations. Cambridge: Polity Press.

Bourdieu P (2005 [2000]) The Social Structures of the Economy. Cambridge: Polity Press.

Bourdieu P and Darbel A (1966) La fin d'un malthusianisme?. In: Darras (éd.) Le partage des bénéfices. Expansion et inégalité en France. Paris: Editions de Minuit: 135-154.

Bourdieu P and Darbel A (1979 [1966]) The Love of Art: European Art Museums and Their Public. Cambridge: Polity Press.

Bourdieu P, Darbel A, Rivet JP and Seibel C (1963) Travail et travailleurs en Algérie, Paris and La Haye: Mouton.

Bourdieu P and Passeron JC (1979 [1964]) The Inheritors: French Students and Their Relation to Culture. Chicago: University of Chicago Press.

Bourdieu P and Passeron JC (1990 [1970]) Reproduction in Education, Society and Culture. New York: Sage.

Bourdieu P and Wacquant LJD (1992) An Invitation to Reflexive Sociology. Chicago: The University of Chicago Press.

Broady D (2002) French prosopography: definition and suggested readings. Poetics 30(5-6): 381-385.

Bühlmann F (2008) The Corrosion of Career? - Occupational Trajectories of Business Economists and Engineers in Switzerland. European Sociological Review 24(5): 601-616.

Bühlmann F (2010) Routes into the British Service Class: Feeder Logics According to Gender and Occupational Groups. Sociology 44(2): 195-212.

Bühlmann F, Benz P, Mach A and Rossier T (2017) Mapping the power of law professors: The role of scientific and social capital. Minerva. A Review of Science, Learning and Policy 55(4): 509-531.

Bühlmann F, David T and Mach A (2012a) The Swiss Business Elite (1980-2000): How the Changing Composition of the Elite Explains the Decline of the Swiss Company Network. Economy and Society 41(2):199-226.

Bühlmann F, David T and Mach A (2012b) Political and economic elites in Switzerland: Personal interchange, interactional relations and structural homology. European Societies 14(5): 727-745.

Bühlmann F, David T and Mach A (2013). Cosmopolitan capital and the internationalization of the field of business elites: Evidence from the Swiss case. Cultural Sociology 7(2): 211229. 
Bühlmann F, Rossier T, and Benz P (2018) The Elite Placement Power of Professors of Law and Economic Sciences. In: Korsnes O, Heilbron J, Hjellbrekke J, Bühlmann F and Savage M (eds.) New Directions in Elite Studies, Oxford and New York: Routledge: 247-264.

Burt RS (1992) Structural Holes. The Social Structure of Competition. Cambridge MA: Harvard University Press.

Charle C, Nagle J, Perrichet M, Richard M and Woronoff D (1980) Prosopographie des élites françaises: XVlème-XXème siècles. Paris: Institut d'histoire moderne et contemporaine (IHMC).

Coleman JC (1990) Foundations of Social Theory. Cambridge MA: Harvard University Press.

Coulangeon P and Duval J (2013) Trente ans après La Distinction de Pierre Bourdieu. Paris: La Découverte.

Coulangeon P and Duval J (2015) The Routledge Companion to Bourdieu's Distinction. Abingdon and New York: Routledge.

Cousin B, Khan S and Mears A (2018) Theoretical and Methodological Pathways for Research on Elites. Socio-Economic Review 16(2): 225-249.

Dalberg T (2019 ; forthcoming) "Structure and Change in the Field of mid-20th c. Human Scientists in Sweden”. In: Blasius J, Lebaron F, Le Roux B and Schmitz A (eds.) Empirical Investigations of Social Space. Cham $(\mathrm{CH})$ : Springer.

Darras (1966) Le partage des bénéfices. Expansion et inégalité en France. Paris: Editions de Minuit.

de Nooy W (2003) Fields and networks: correspondence analysis and social network in the framework of field theory. Poetics 31: 305-327.

de Nooy W, Mrvar A and Batagelj V (2018 [2005]) Exploratory Social Network Analysis with Pajek. Cambridge: Cambridge University Press.

Denord F (2015) Géométrie des réseaux. In: Lebaron F and Le Roux B (eds.) $L a$ méthodologie de Pierre Bourdieu en action. Espace culturel, espace social et analyse des données. Paris: Dunod: 59-78.

Denord F, Hjellbrekke J, Korsnes O, Lebaron F and Le Roux B (2011) Social capital in the field of power: the case of Norway. The Sociological Review 59(1): 86-108.

Denord F, Lagneau-Ymonet P and Thine S (2018) Primus inter pares? The French field of power and its power elite. Socio-Economic Review 16(2): 277-306.

Eichenberger P and Ginalski S (2017) 'Si vis pacem, para bellum' - the construction of business cooperation in the Swiss machinery industry. Socio-Economic Review 15(3): 615635 . 
Ellersgaard CH, Larsen AG and Munk MD (2012) A Very Economic Elite: The Case of the Danish Top CEOs. Sociology 47(6): 1051-1071.

Ellersgaard CH, Lundig JA, Henriksen LF and Larsen AG (2019; forthcoming) Pathways to the power elite: The organizational landscape of elite careers. Sociological Review.

Eloire F (2018) The Bourdieusian Conception of Social Capital: A Methodological Reflection and Application. Forum for Social Economics 47(3-4): 322-341.

Fourcade M (2009) Economists and Societies. Discipline and Profession in the United States, Britain, and France, 1890s to 1990s. Princeton: Princeton University Press.

Gabadinho A, Ritschard G, Studer M and Müller NS (2011) Mining sequence data in $R$ with the TraMineR package: A user's guide. Geneva: University of Geneva.

Gauthier JA, Bühlmann F and Blanchard P (2014) Introduction: Sequence Analysis in 2014. In: Blanchard P, Bühlmann F and Gauthier JA (eds.). Advances in Sequence Analysis: Theory, Method, Applications. New York: Springer: 1-17.

Godechot O (2010) Interpréter les réseaux sociaux. In: Paugam S (ed.) L'enquête sociologique. Paris, PUF: 333-355.

Granovetter M (1973) The Strength of Weak Ties. American Journal of Sociology 78(6): 1360-1380.

Grenfell M (2014) Bourdieu and Data Analysis. In: Grenfell M and Lebaron F (eds.) Bourdieu and Data Analysis: Methodological Principles and Practice. Oxford: Peter Lang: 733.

Grenfell M and Lebaron F (eds.) (2014) Bourdieu and Data Analysis: Methodological Principles and Practice. Oxford: Peter Lang.

Hjellbrekke J (2018) Multiple Correspondence Analysis for the Social Sciences. Oxford and New York: Routledge.

Hjellbrekke J and Korsnes O (2016) Women in the Field of Power. Sociologica 2: 1-28.

Hjellbrekke J and Korsnes O (2018) A place at what table? An analysis of symbolic capital hierarchies at the annual dinner of Norges Bank (the Norwegian central bank). In: Korsnes O, Heilbron J, Hjellbrekke J, Bühlmann F and Savage M (eds.) New Directions in Elite Studies. Oxford and New York: Routledge: 93-112.

Kárady V and Nagy PT (2019) Institutionalization and Professionalization of the Social Sciences in Hungary Since 1945. In: Fleck C, Duller M and Kárady V. Shaping Human Science Disciplines. Institutional Developments in Europe and Beyond, Cham (CH): Palgrave Macmillan : 289-325.

Klüger E (2018) Mapping the Inflections in the Policies of the Brazilian National Economic and Social Development Bank during the 1990s and 2000s within Social Spaces and Networks. Historical Social Research 43(3): 274-302. 
Lahire B (1999) Champ, hors-champ, contre-champ. In: Lahire B (ed.) Le travail sociologique de Pierre Bourdieu. Dettes et critiques. Paris: Editions La Découverte: 23-57.

Larsen AG, Andrade SB and Ellersgaard CH (2016) Soc.ca: Specific and Class Specific Multiple Correspondence Analysis for the Social Sciences in R. Online version:

https://cran.r-project.org/web/packages/soc.ca/soc.ca.pdf.

Le Roux B and Rouanet H (2010) Multiple correspondence analysis. Los Angeles: SAGE Publications Inc.

Lebaron F (2015) L'espace social. Statistique et analyse géométrique des données dans l'œuvre de Pierre Bourdieu. In: Lebaron F and Le Roux B (eds.) La méthodologie de Pierre Bourdieu en action. Espace culturel, espace social et analyse des données. Paris: Dunod: 4358.

Lebaron F and Le Roux B (eds.) (2015) La méthodologie de Pierre Bourdieu en action. Espace culturel, espace social et analyses de données. Paris: Dunod.

Lemercier C (2005) Analyse de réseaux et histoire. Revue d'histoire moderne et contemporaine 52(2): 88-112.

Lemercier C and Picard E (2011) Quelle approche prosopographique?. Rollet L and Nabonnand P (eds.) Objets et méthodes biographiques en histoire des sciences. Nancy: Presses universitaires de Nancy: 605-630.

Levy R and Bühlmann F (2016) Towards a socio-structural framework for life course analysis. Advances in Life Course Research 30: 30-42.

Lin N (2001) Social Capital. A Theory of Social Structure and Action. Cambridge: Cambridge University Press.

Lunding JA (2017) The Danish Field of Power. A multiple correspondence analysis of the contemporary structures of power in Denmark. Copenhagen: Department of Sociology. University of Copenhagen. Master Thesis.

MacIndoe H and Abbott A (2004) Sequence Analysis and Optimal Matching Techniques for Social Science Data. In: Hardy M and Bryman A (eds.) Handbook of Data Analysis. London: Sage: $387-406$.

Mercklé P (2011 [2004]) Sociologie des réseaux sociaux. Paris: La Découverte.

Mercklé P (2017) Une traversée de l'adolescence. Cultures, classes, réseaux: Unpublished dissertation of habilitation à diriger des recherches.

Mills CW (1956) The Power Elite. Oxford: Oxford University Press.

Robette N and Roueff O (2017) L'espace contemporain des goûts culturels. Homologies structurales entre domaines de pratiques et entre classes sociales. Sociologie 8(4): 369-394. 
Robson K and Sanders C (eds.) (2009) Quantifying Theory. Pierre Bourdieu. New York, Springer.

Roose H (2015) Signs of 'Emerging' Cultural Capital? Analysing Symbolic Struggles Using Class Specific Analysis. Sociology 49(3): 556-573.

Rossier T (2017) Affirmation et transformations des sciences économiques en Suisse au XXe siècle. Unpublished doctoral dissertation. Lausanne: University of Lausanne, Faculté des SSP.

Rossier T and Bühlmann F (2018) The Internationalisation of Economics and Business Studies: Import of Excellence, Cosmopolitan Capital, or American Dominance?. Historical Social Research 43(3): 189-215.

Rossier T, Bühlmann F and Mach A (2017) The Rise of Professors of Economics and Business Studies in Switzerland: Between Scientific Reputation and Political Power. European Journal of Sociology 58(2): 295-326.

Rossier T and Fillieule O (2019; forthcoming) Devenir(s) militants. Les conséquences biographiques de l'engagement des soixante-huitard.e.s français.e.s. Revue française de science politique 69(4).

Savage M and Silva E (2013) Field Analysis in Cultural Sociology. Cultural Sociology 7(2): 111-126.

Savage M, Warde A and Devine F (2005) Capitals, assets, and resources: some critical issues. The British Journal of Sociology 56(1): 31-47.

Schmidt-Wellenburg C (2018) Struggling over Crisis. Discoursive Positionings and Academic Positions in the Field of German-Speaking Economists. Historical Social Research 43(3): 147-188.

Stone L (1971) Prosopography. Daedalus 100(1): 46-71.

Studer M (2013) WeightedCluster Library Manual. A practical guide to creating typologies of trajectories in the social sciences with R. LIVES Working Papers 24: 1-34.

Swartz DL (1997) Culture and Domination. The Social Theory of Pierre Bourdieu. Chicago: The University of Chicago Press.

Timans R and Heilbron J (2018) Degrees of transnationalization. The case of the Dutch business elite. In: Korsnes O, Heilbron J, Hjellbrekke J, Bühlmann F and Savage M (eds.) New Directions in Elite Studies. Oxford and New York: Routledge: 46-72.

Toft M (2018a) Upper-class trajectories: capital-specific pathways to power. Socio-Economic Review 16(2): 341-364.

Toft M (2018b) Enduring contexts: Segregation by affluence throughout the life course. The Sociological Review 66(3): 645-664. 
Toft M (2019) Mobility closure in the upper class: assessing time and forms of capital. British Journal of Sociology 70(1): 109-137. 
Appendix: Class-specific analyses on women, men, Swiss and non-Swiss Citizens as illustrative variables: Graphs by axis

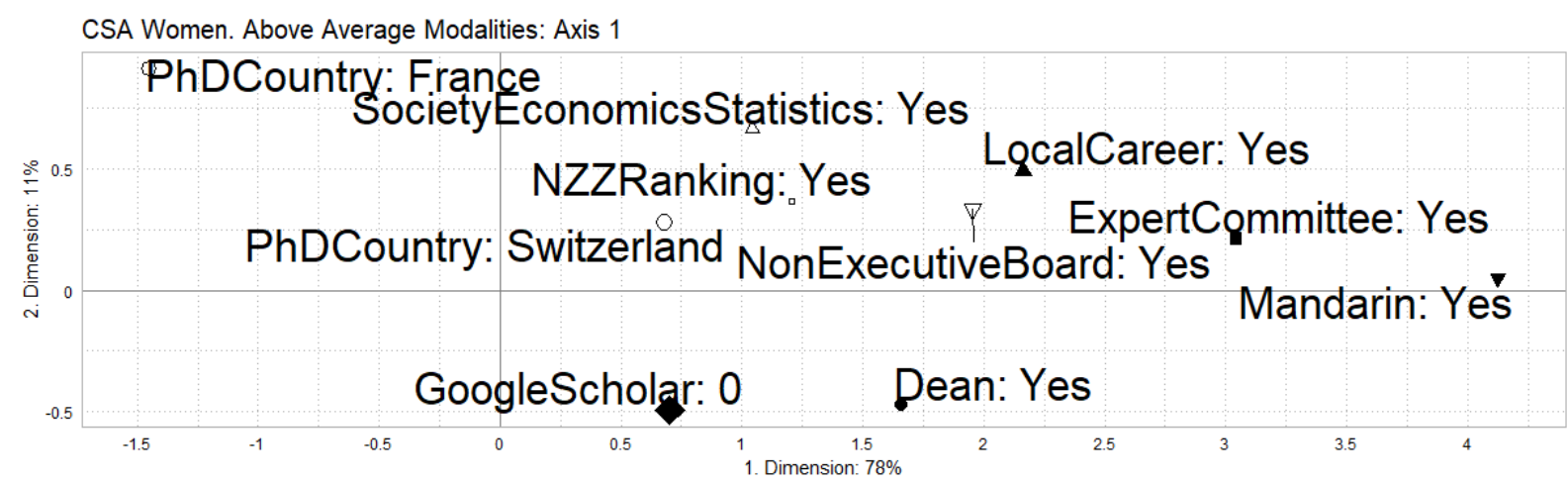

CSA Women. Above Average Modalities: Axis 2

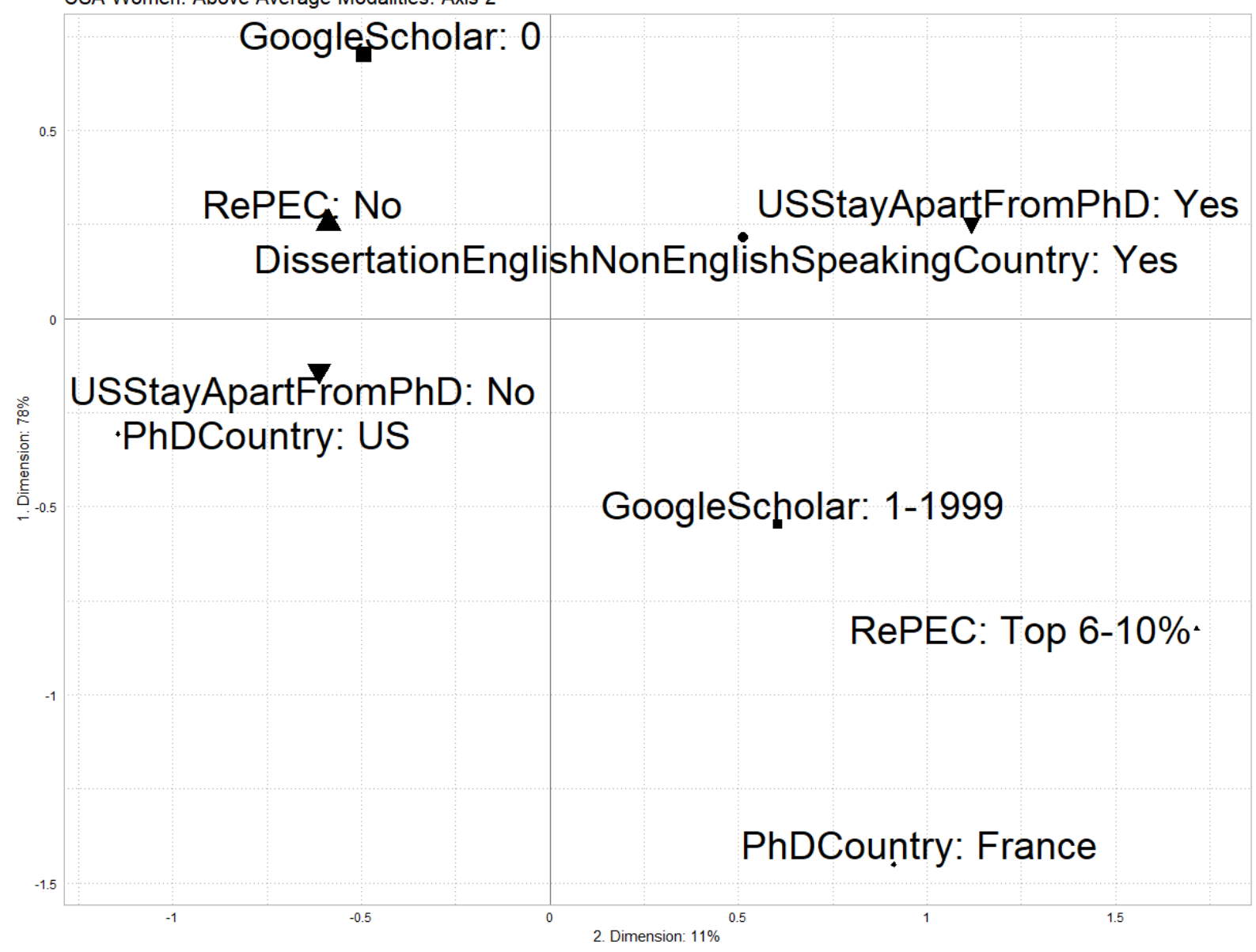




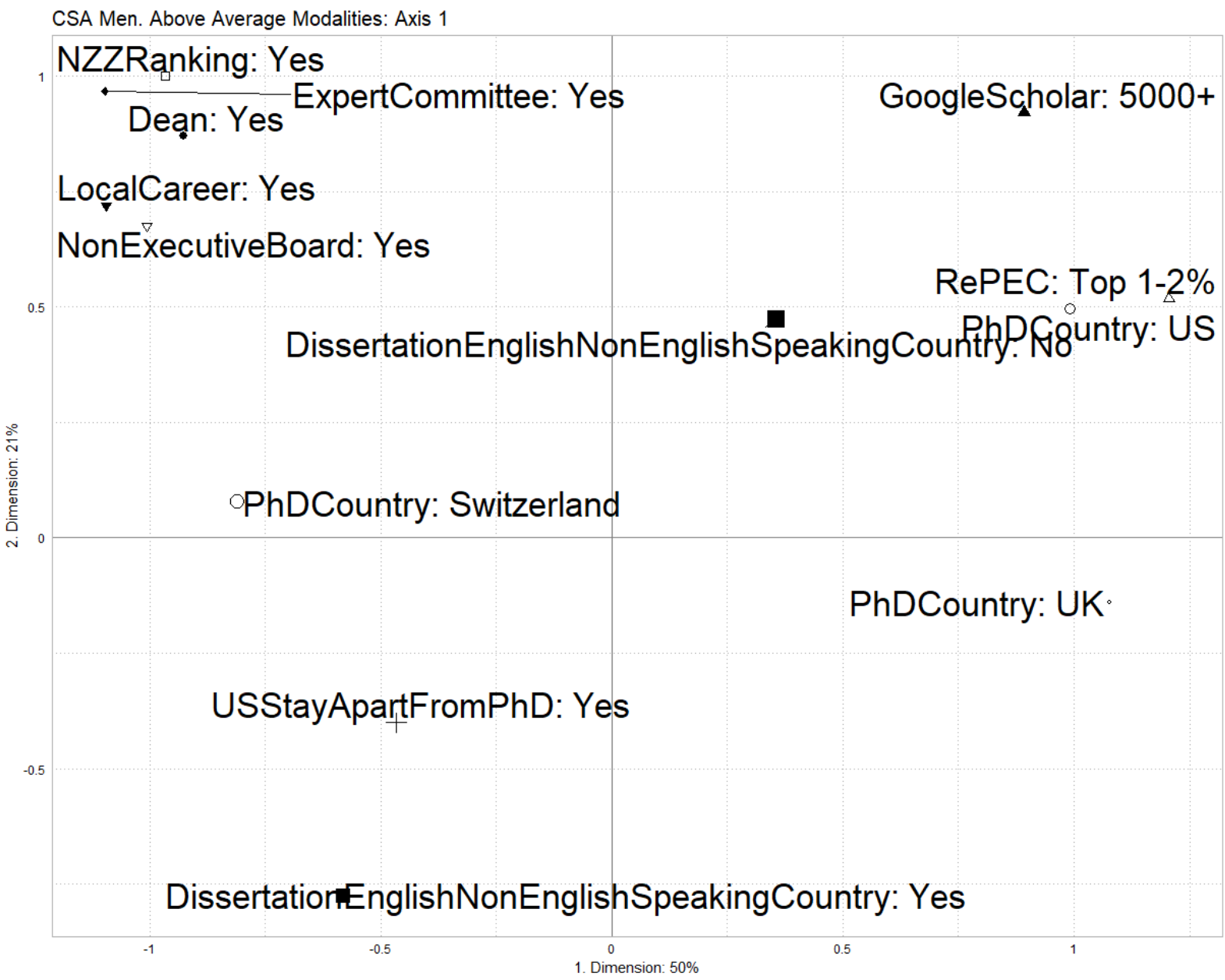




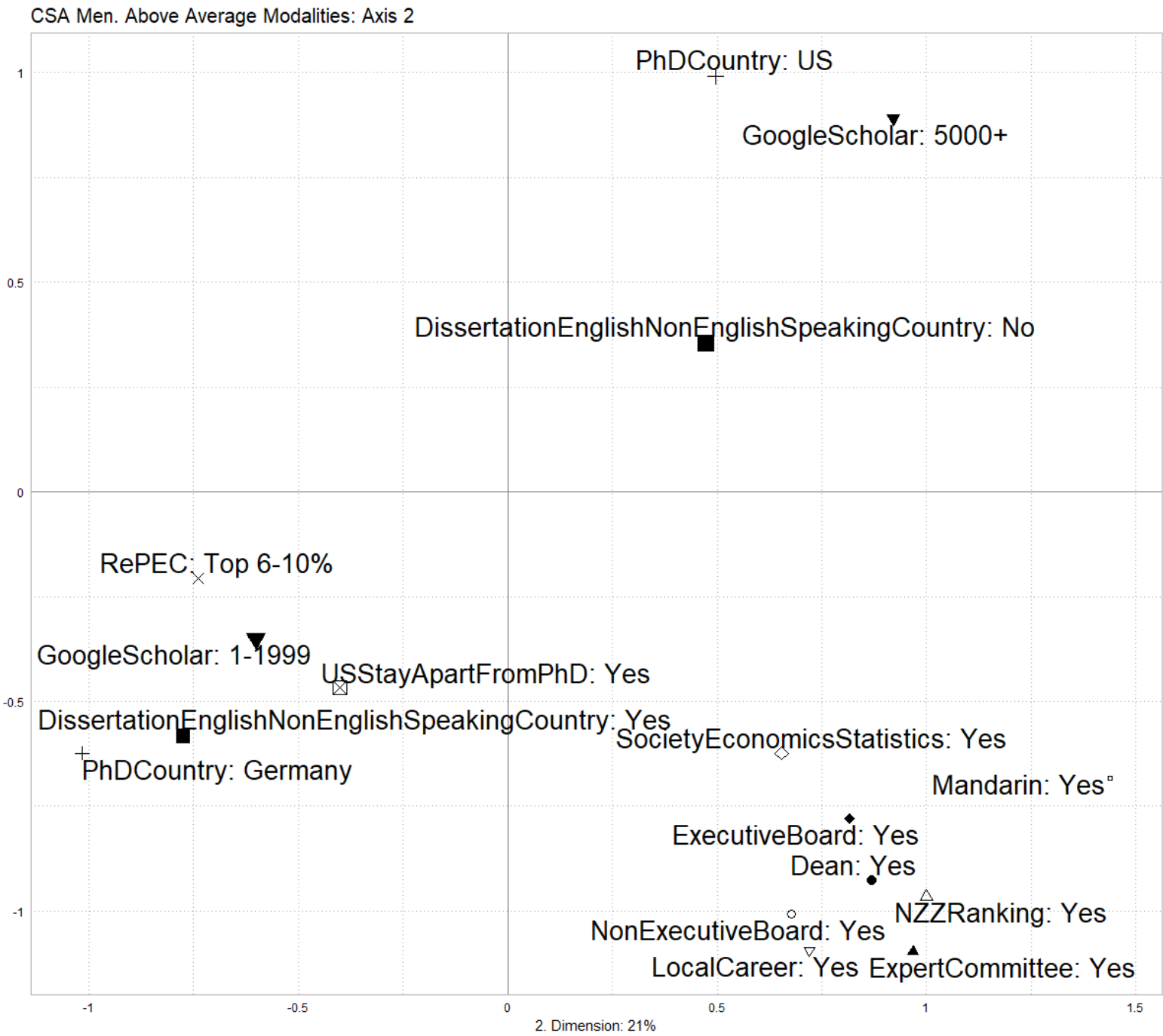




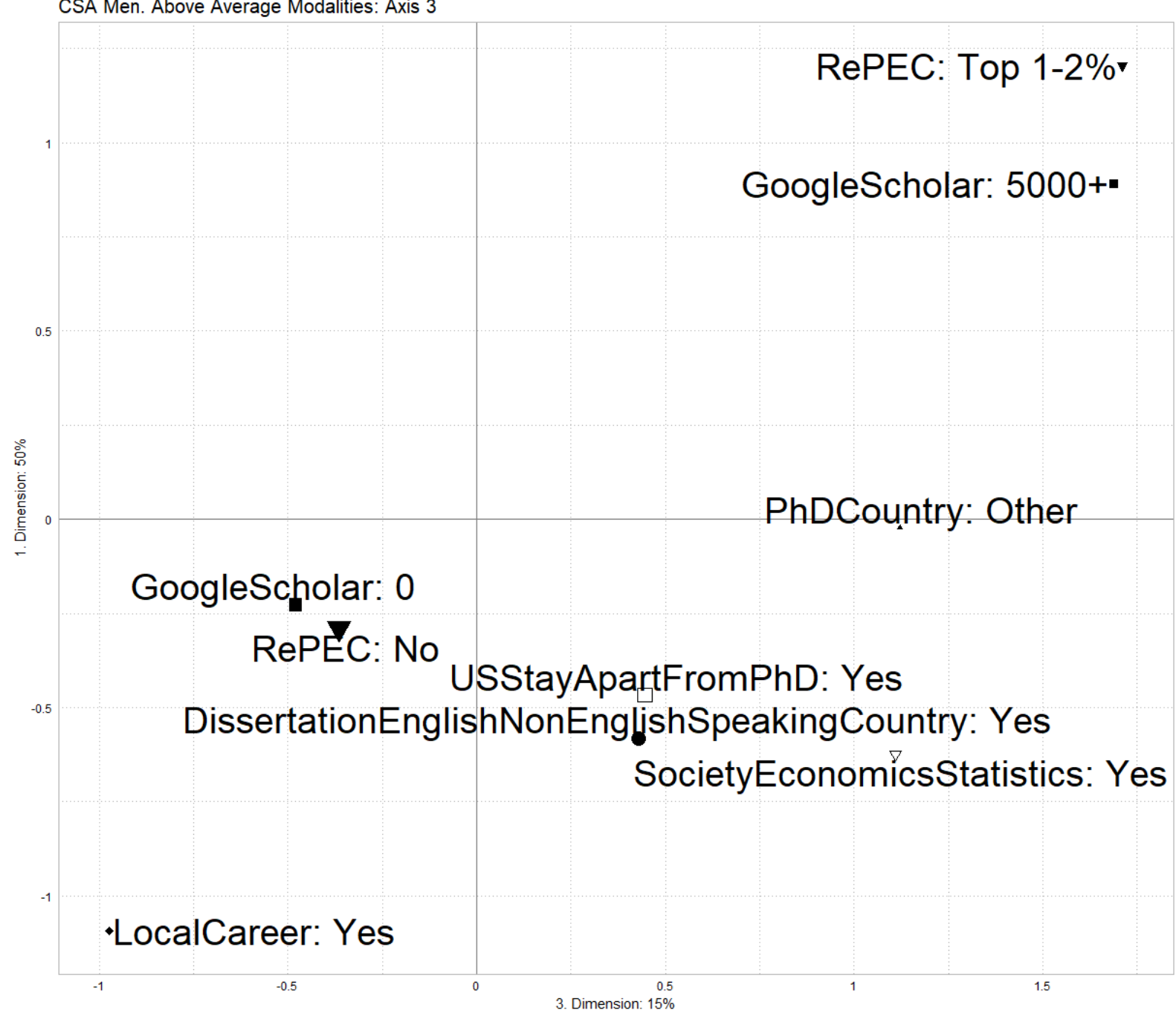




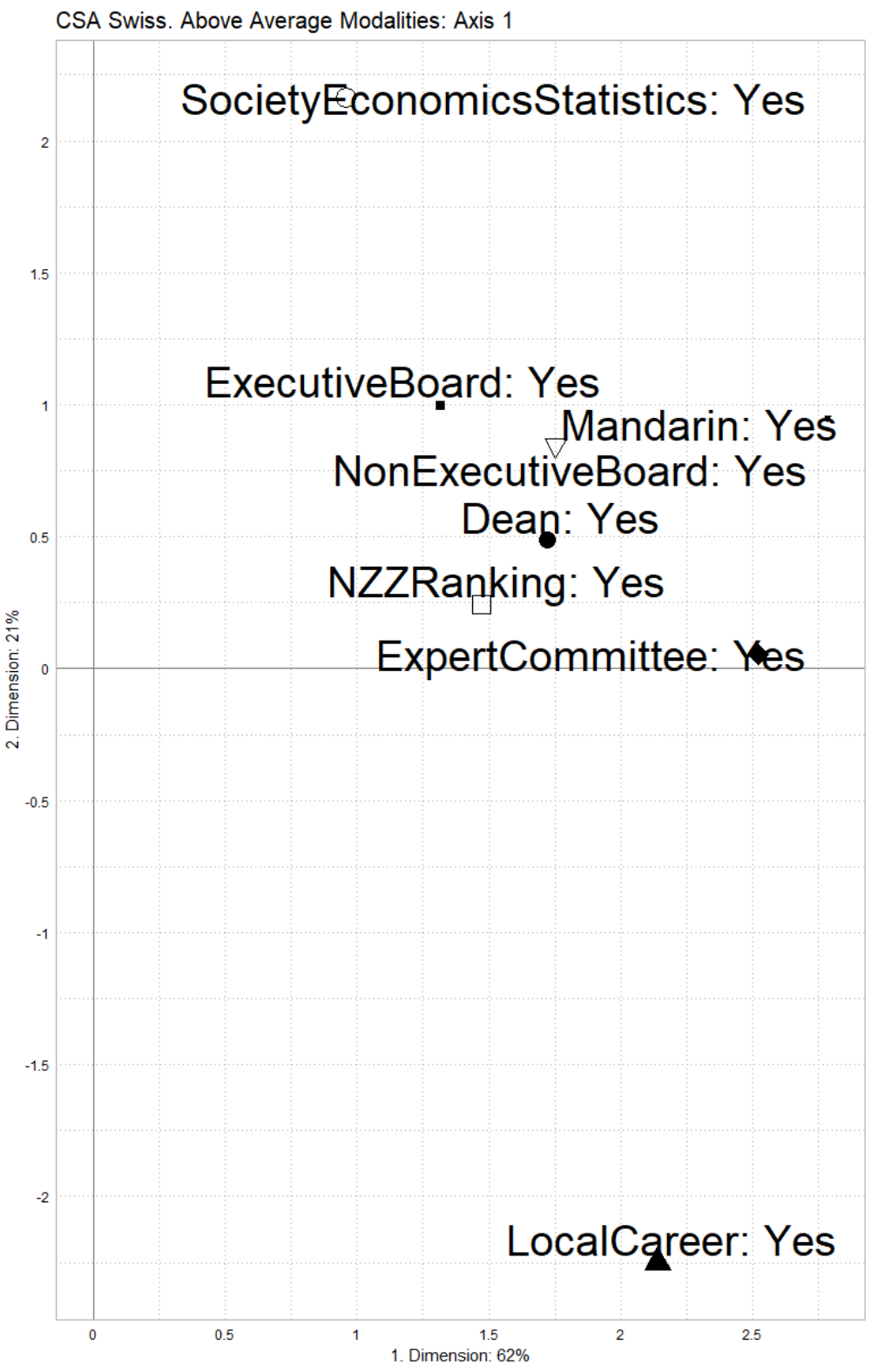




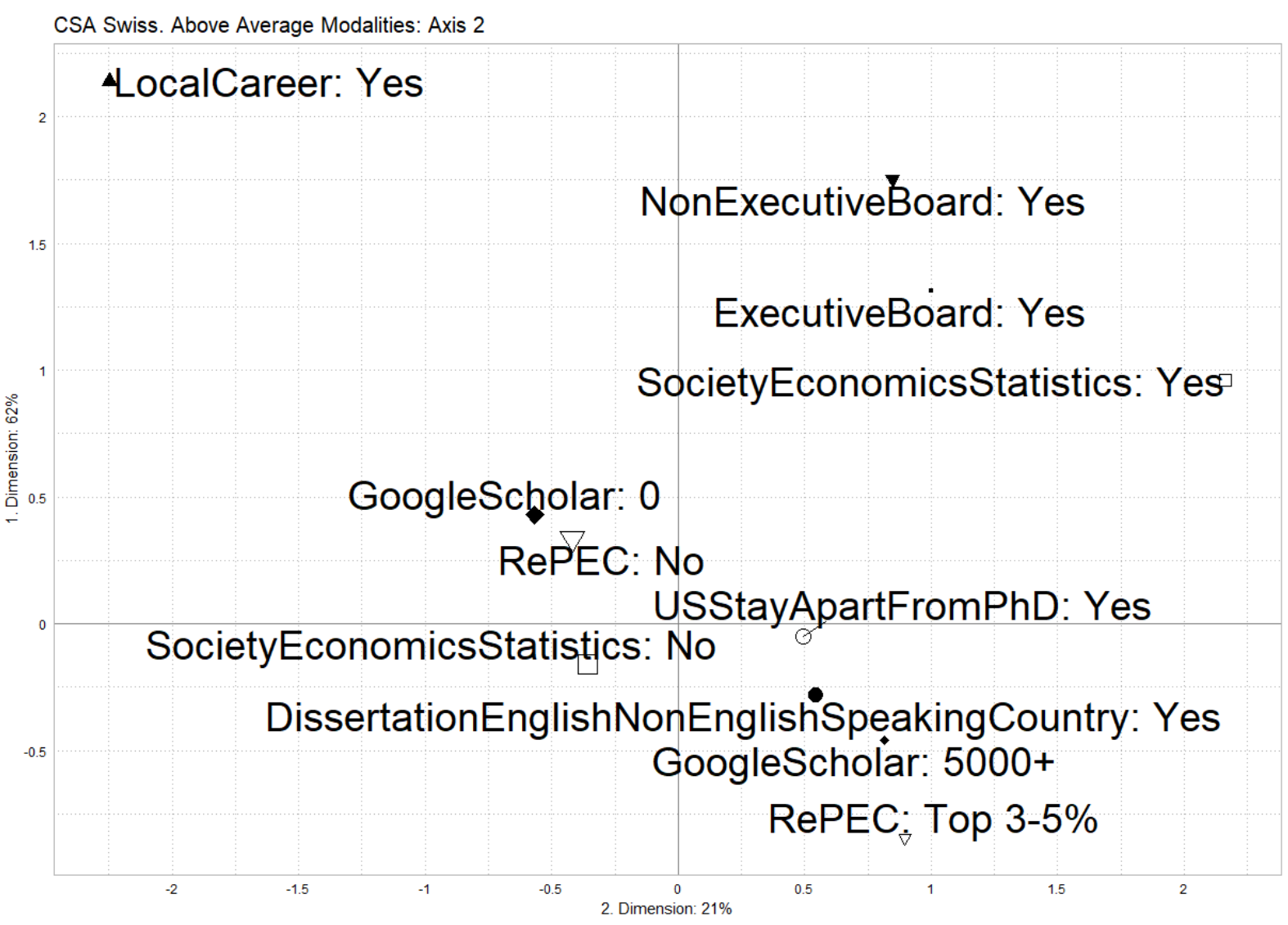



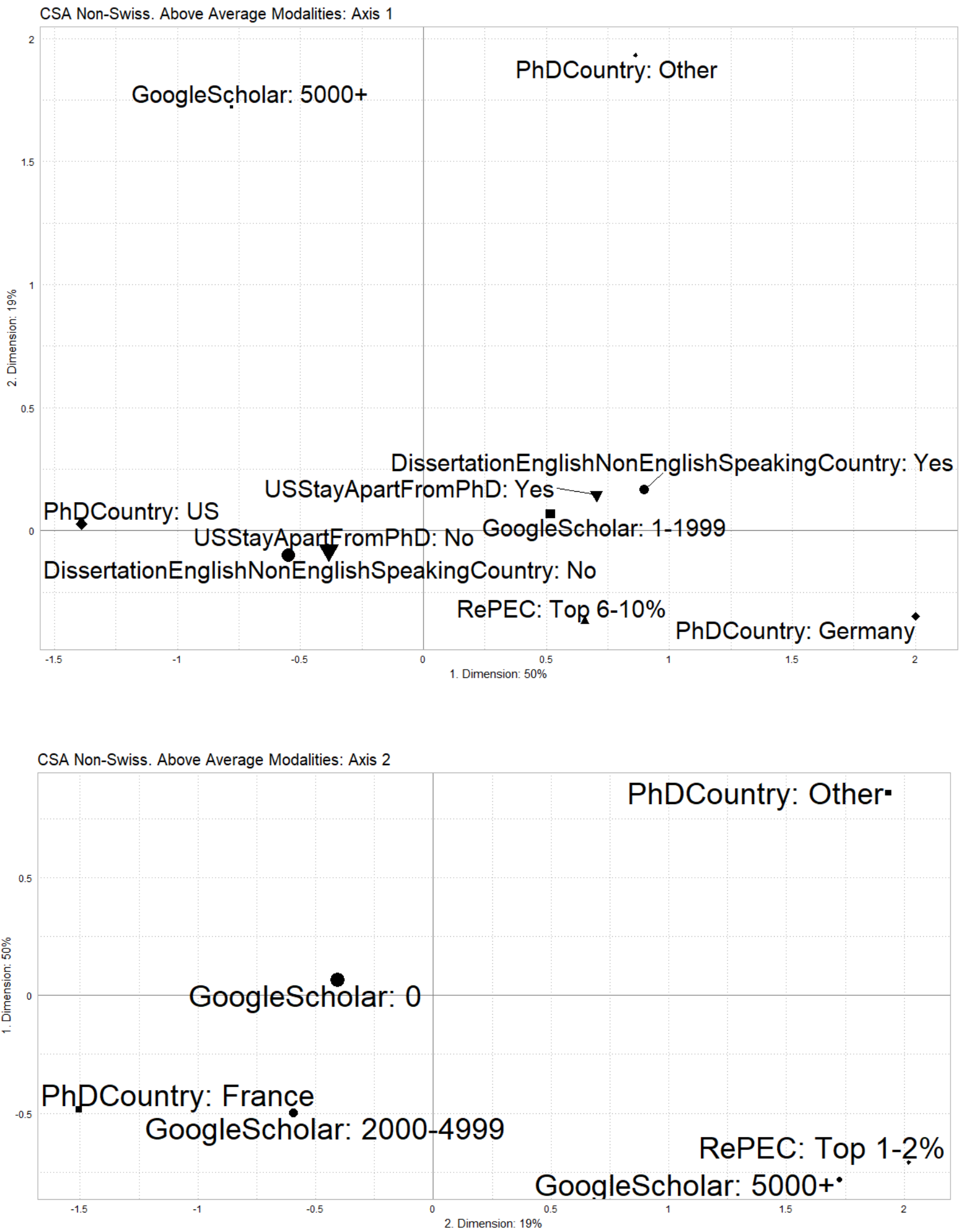


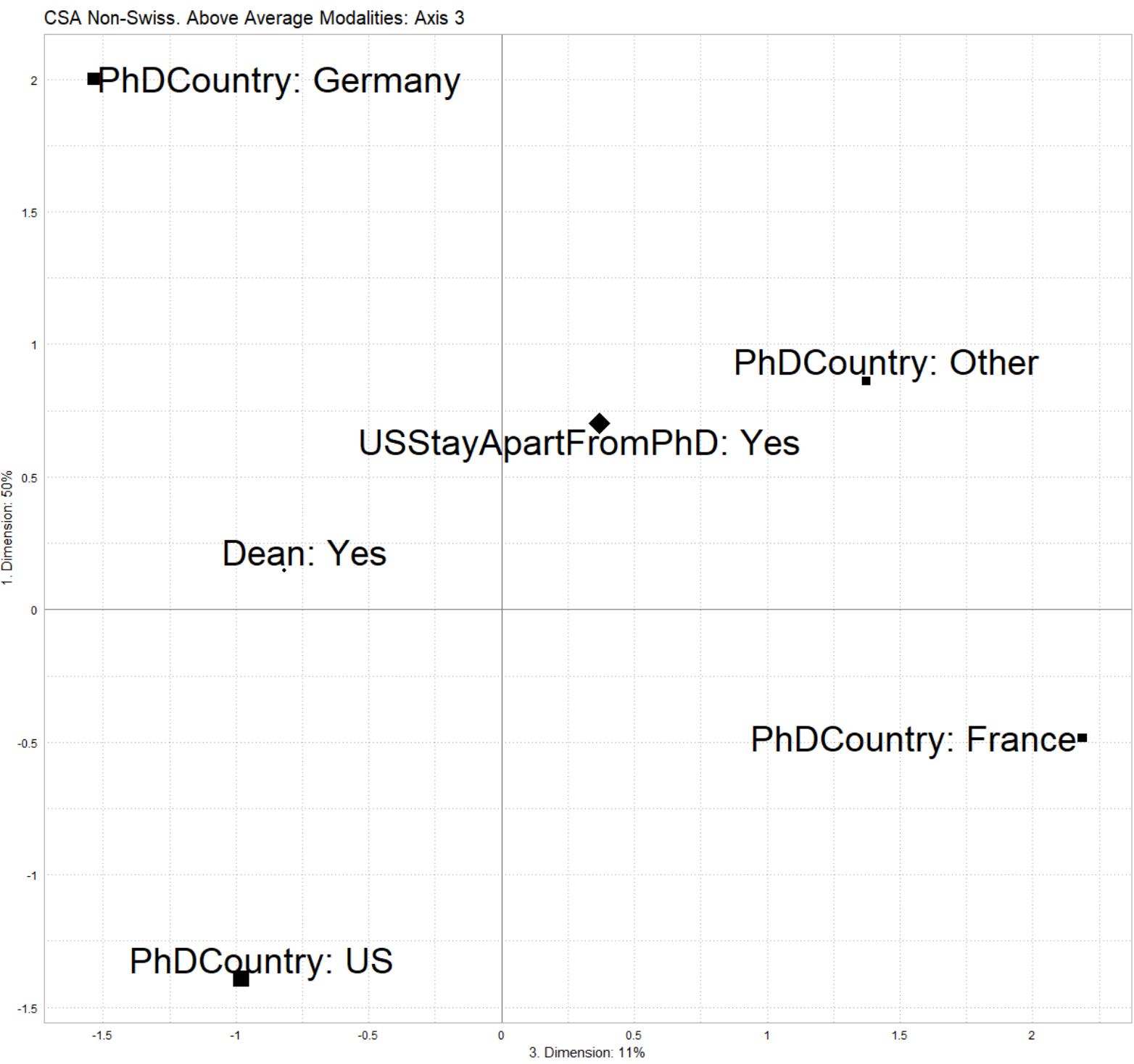

